\title{
Reconnaissance of the
}

Ground-Water Resources

of the Elkhorn River Basin

Above Pilger, Nebraska

GEOLOGICAL SURVEY WATER-SUPPLY PAPER 1360-I

Prepared as part of the program of the Department of the Interior for the development of the Missouri River basin

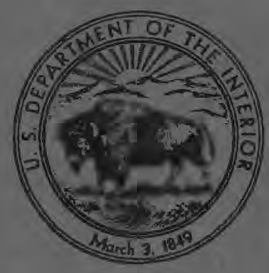




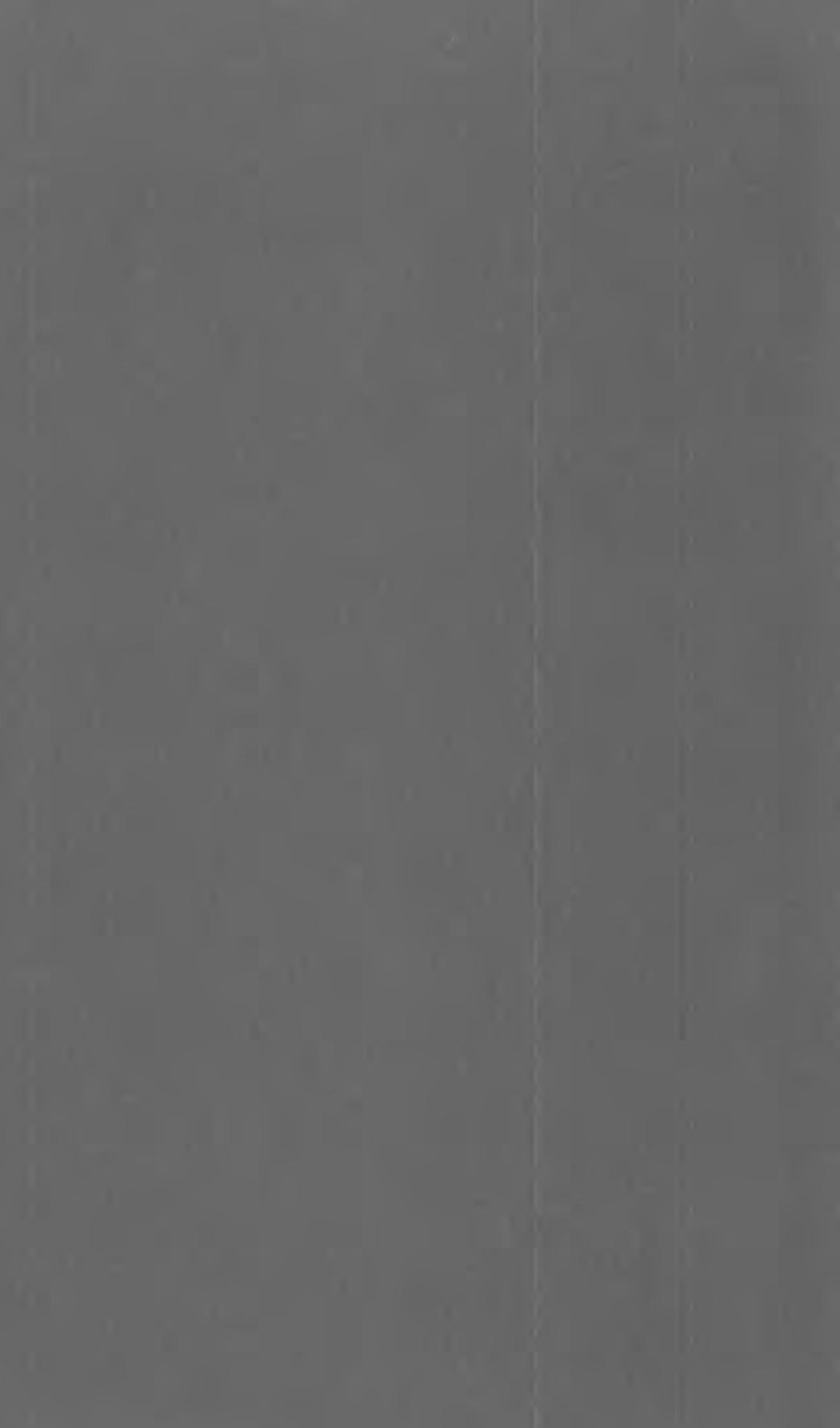




\section{Reconnaissance of the}

Ground-Water Resources of the Elkhorn River Basin Above Pilger, Nebraska by THOMAS G. NEWPORT With a section on Chemical Quality of the Water By ROBERT A. KRIEGER CONTRIBUTIONS TO THE HYDROLOGY OF THE UNITED STATES GEOLOGICAL SURVEY WATER-SUPPLY PAPER 1360-I

Prepared as part of the program of the Department of the Interior for the development of the Missouri River basin

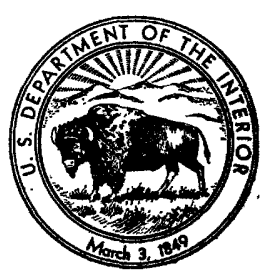




\section{UNITED STATES DEPARTMENT OF THE INTERIOR}

FRED A. SEATON, Secretary

\section{GEOLOGICAL SURVEY}

Thomas B. Nolan, Director Washington 25, D. C. 


\section{CONTENTS}

Abstract

Introduction

Purpose and scope of the investigation

Location and extent of the area........................ 716

Methods of investigation .

Well-numbering system . .

Acknowledgments................. 719

Previous investigations and reports...

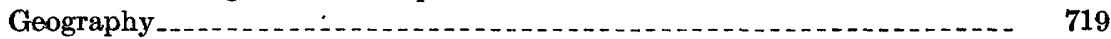

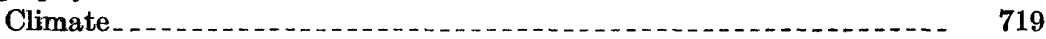

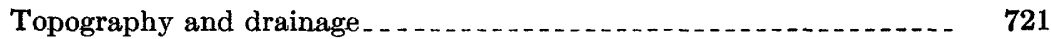

Stratigraphic units and their water-yielding properties_._............ 721

Ground water

Occurrence, source, and movement

Ground-water regions $\ldots . . \ldots \ldots \ldots \ldots$

Sand Hills region................. 724

Central region

Northern drift region.

Fluctuations of the water table

Ground-water discharge

Evapotranspiration $\ldots \ldots \ldots$

Seepage into streams

Underflow _.......

Withdrawals from wells.

Domestic and livesțock water supplies_._._._.

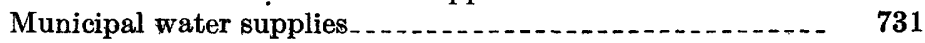

Industrial water supplies.

Irrigation water supplies..... 732

Potential ground-water development.............. 732

Chemical quality of the water, by Robert A. Krieger..._.

Chemical quality of the water in relation to use

Logs of test holes and wells . . .

Selected bibliography $\ldots$

Index . . . . . 


\section{ILLUSTRATIONS}

Plate 44. Map of the Elkhorn River basin above Pilger, Nebr., showing location of irrigation wells, public supply wells, test holes, wells sampled for chemical analyses of water, and average annual temperature and precipitation............. In pocket

45. Annual precipitation at nine climatological stations in the Elkhorn River basin, Nebraska

Frgure 82. Map of Nebraska showing area described

83. Sketch showing well-numbering system

84. Maximum, minimum, and average monthly precipitation, and cumulative departure from average annual precipitation at

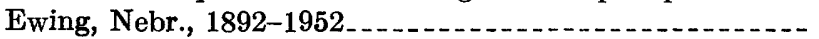

85. Map of the Elkhorn River basin above Pilger, Nebr., showing

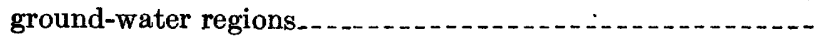

86. Hydrographs of the water level in five wells in the Elkhorn River basin, Nebraska, 1935-54............................

87. Hydrographs of the water level in nine wells in the Elkhorn River basin, Nebraska, 1950-54........................

\section{TABLES}

TABLE 1. Generalized section of the stratigraphic units and their wateryielding properties, Elkhorn River basin above Pilger, Nebr

2. Municipal water supplies

3. Mineral constituents and related characteristics of ground water from Quaternary deposits

4. Mineral constituents and related characteristics of surface

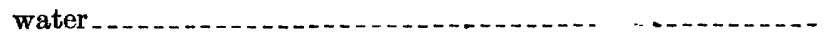

5. Logs of test holes and wells, Elkhorn River basin, Nebraska - -

6. Records of wells in Elkhorn River basin, Nebraska........ 


\section{RECONNAISSANGE OF THE GROUND-WATER RESOURGES OF THE ELKHORN RIVER BASIN ABOVE PILGER, NEBRASKA}

\section{By Thomas G. Newport}

\section{ABSTRACT}

The Elkhorn River is one of the principal tributaries of the Platte River system. It drains an area in northeastern Nebraska which contains some of the best agricultural land in the State. The area of this study includes the Elkhorn River basin above Pilger, Nebr., an area of about 4,000 square miles. During the past few years, several areas have been irrigated with ground water, and the possibility of expanding the use of ground water has been emphasized. The western part of the basin is in the Sand Hills region of Nebraska; there the river is a sluggish, meandering stream which flows through poorly drained hay meadows. East of the Sand Hills region, the basin lies in a loess-mantled plain; still farther east, it lies in the glacial-drift region, where the principal mantle deposits are till capped by loess.

The rock formations exposed in the area were deposited principally in Quaternary time. Silt, sand, and gravel of Pleistocene age overlie the Ogallala formation of Pliocene age in the western part of the basin. The Ogallala formation feathers out toward the east, and the deposits of Pleistocene age rest directly on rocks of Cretaceous age, which underlie the entire basin.

The Ogallala formation and many of the deposits of Pleistocene age are saturated and contain the most important aquifers throughout most of the upper Elkhorn River basin. Very little water is pumped from the Ogallala formation, however, because a more copious supply usually exists in the overlying sand and gravel beds of Pleistocene age. The saturated sand and sand and gravel deposits of Pleistocene and Pliocene age are absent in some parts of the area; in these places a few wells obtain water from the Dakota sandstone. The water in the Dakota sandstone is generally of poor quality and is used only where other sources of supply are not available.

The ground-water reservoir is recharged by local precipitation. Water is discharged from the ground-water reservoir by subsurface movement eastward and southeastward, by evaporation, by transpiration in areas of shallow water table, by seepage into perennial streams, and by withdrawal from wells.

All the domestic, stock, public, and industrial water supplies and most of the irrigation water supplies are obtained from wells. The irrigation wells are not pumped during years when the rainfall is sufficient for agricultural purposes; 1952 was one such year.

The report includes records of 131 wells; logs of 36 test holes and water wells; and chemical analyses of 29 samples of ground water and 14 samples of surface water.

The chemical quality of most of the ground water is satisfactory for irrigation.

Available data indicate that the ground-water resources of the basin are capable of additional development; however, it is clear also that the data are in- 
sufficient to determine the quantity of additional ground water that could be withdrawn or the effects of such withdrawal upon the normal streamflow. Relatively large-scale developments in the future should be preceded and accompanied by comprehensive water-resources and land-utilization studies of the basin; such studies should be preceded by the preparation of adequate topographic maps.

\section{INTRODUCTION}

\section{PURPOSE AND SCOPE OF THE INVESTIGATION}

This report was prepared to summarize existing data that pertain to the ground-water resources of the area studied, to present a brief annotated bibliography of previous reports that pertain to the groundwater resources, to collect and summarize data concerning public, industrial, and irrigation well pumpage, to evaluate the existing hydrologic data, and to delineate those parts of the basin, if any, where detailed ground-water studies are needed to understand more fully the ground-water resources.

The report includes a brief description of geology and topography, a summary of the chemical analyses of 29 samples of ground water and 14 samples of surface water, and a discussion of the occurrence and quality of the water. The investigation was made during 1952 and the spring and early summer of 1953.

The study was under the direct supervision of C. F. Keech, district engineer of the Ground Water Branch of the United States Geological Survey in Nebraska. The quality-of-water section was prepared under the direct supervision of P. C. Benedict, regional engineer of the Quality of Water Branch, U. S. Geological Survey, for the Missouri River basin.

\section{LOCATION AND EXTENT OF THE AREA}

The area studied is the part of the Elkhorn River drainage basin west of the eastern boundary of Stanton County, Nebr., and includes parts of Antelope, Holt, Knox, Madison, Pierce, Platte, Rock, Stanton, and Wheeler Counties, Nebr. The basin, which the area studied will hereafter be called in this report, is about 130 miles long from east to west, averages about 31 miles in width from north to south, and covers about 4,000 square miles. (See pl. 44 and fig. 82.)

\section{METHODS OF INVESTIGATION}

Records of 131 wells were obtained from well drillers and owners. (See table 6.) The depth of water in 37 wells and the depths of 15 wells were measured with a steel tape. Reported depths to water and depths of wells are given for those wells that were not or could not be measured. Eight water samples were collected from representative wells for chemical analyses. Analyses were available for 19 samples of ground water and 14 samples of surface water previously collected from the basin. 
GROUND-WATER RESOURCES, ELKHORN RIVER BASIN, NEBRASKA 717

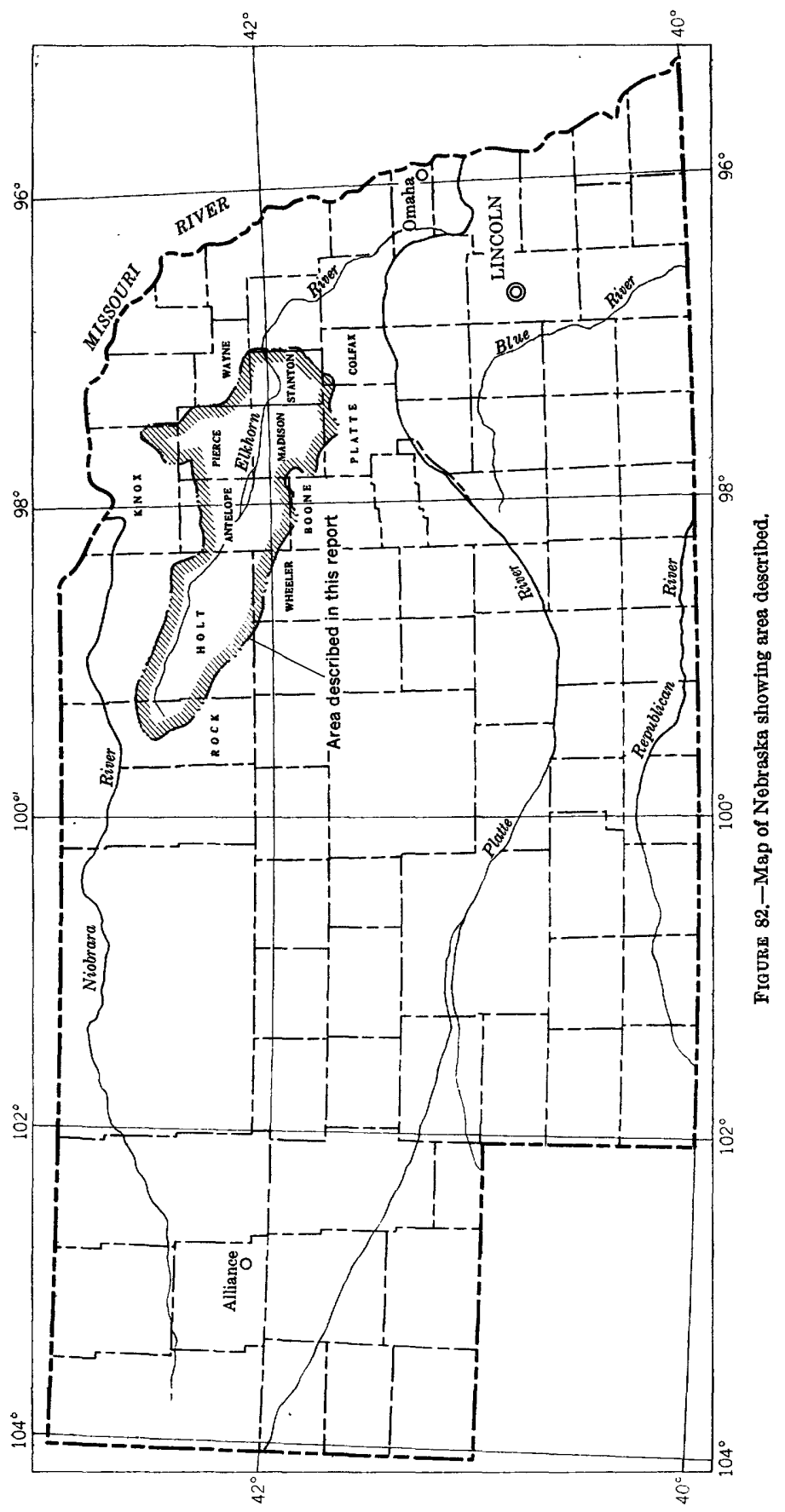


Field data were plotted on county highway and transportation maps at a scale of $1: 31,680$. Plate 44 was compiled from these maps. The wells and test holes were located from known points by means of an automobile odometer.

\section{WELL-NUMBERING SYSTEM}

Wells and test holes are numbered according to their location within the United States Bureau of Land Management's system of land subdivision. The well number gives the location by township, range, section, and position within the section. The well-numbering system is illustrated in figure 83. The first numeral indicates the township, the second the range, and the third the section in which a well is located. The first letter following the section number denotes the quarter section; the second, the quarter-quarter section (40-acre

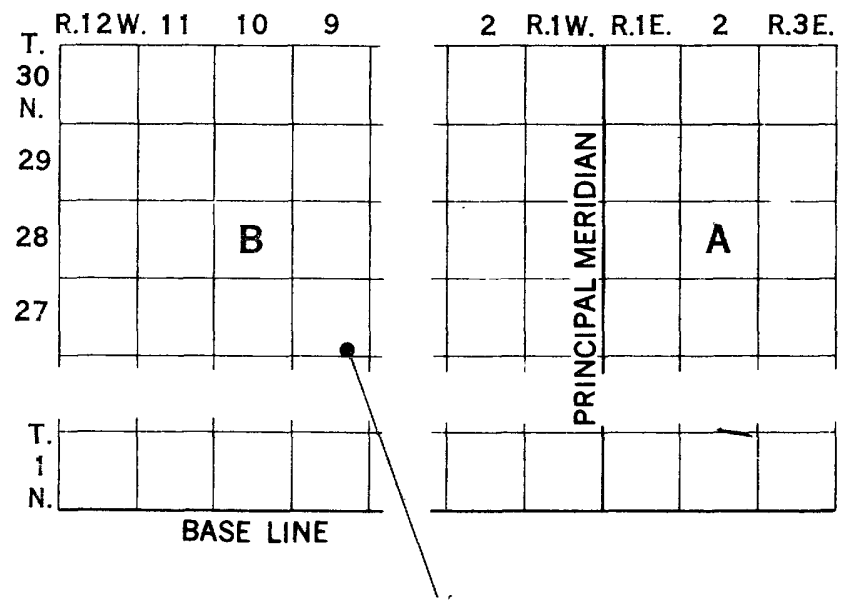

Well B27-9-34da

\begin{tabular}{|c|c|c|c|c|c|}
\hline \multicolumn{7}{|c|}{ R. 9 W. } \\
\hline 6 & 5 & 4 & 3 & 2 & 1 \\
\hline 7 & 8 & 9 & 10 & 11 & 12 \\
\hline 18 & 17 & 16 & 15 & 14 & 13 \\
\hline 19 & 20 & 21 & 22 & 23 & 24 \\
\hline 30 & $\begin{array}{c}\text { T. } \\
\text { N. }\end{array}$ \\
\hline 31 & 32 & 33 & 34 & 35 & 36 \\
\hline
\end{tabular}

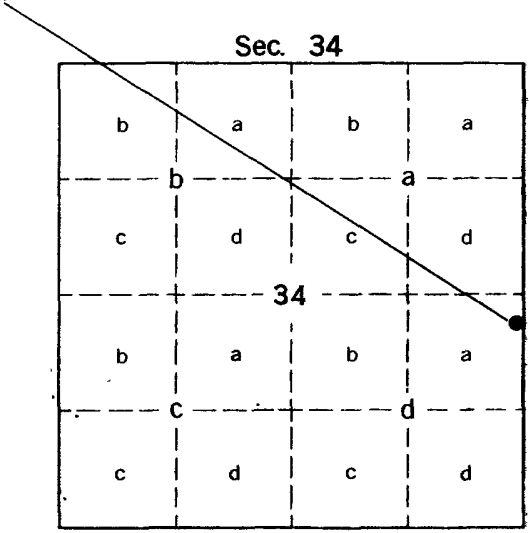

FIGURE 83.--Sketch showing well-numbering system. 
tract). The subdivisions of the section are lettered $a, b, c$, and $d$ in a counterclockwise direction, beginning in the northeast quarter or quarter-quarter. Consecutive numerals follow the lowercase letters when more than one well is in a 40 -acre tract. The capital letter " $A$ " precedes the well number if the well is east of the sixth principal meridian.

\section{ACKNOWLEDGMENTS}

The personnel of district offices of the United States Soil Conservation Service was especially helpful and cooperative during the course of the field work. E. C. Reed, director of the Conservation and Survey Division of the University of Nebraska, supplied much useful advice and information. Special acknowledgment is also due property owners and well drillers, who were very cooperative in giving information on wells.

\section{PREVIOUS INVESTIGATIONS AND REPORTS}

Existing literature was reviewed to determine the available published data pertaining in whole or in part to the occurrence and utilization of ground water in the basin. A short annotated bibliography of that literature is given in the Selected bibliography at the end of this report. Soil-survey reports by the United States Department of Agriculture on Antelope, Holt, Knox, Madison, Pierce, Platte, Rock, and Stanton Counties also are available but not shown in the Selected bibliography. These reports contain data concerning climate, agriculture, and soil and are of interest in connection with the use of water in the basin.

\section{GEOGRAPHY}

\section{CIIMATE}

The climate of the basin is continental with a rather wide range in temperature between winter and summer; generally, it is well suited to raising livestock and growing of feed and grain crops. The spring months are cool and have considerable rain; the summer months are warm and have moderate precipitation; the autumn months are pleasant with only occasional rains; and the winter months are characterized by frequent low temperatures that are usually accompanied by snow. The range in topographic relief is insufficient to cause appreciable climatic differences from place to place. The average annual temperature and precipitation at nine United States Weather Bureau stations in the basin are shown on plate 44. Plate 45 shows graphically the annual precipitation at the nine stations over their periods of record.

The maximum, minimum, and average monthly precipitation and the cumulative departure from average annual precipitation, at Ewing, Nebr., which is near the center of the basin, are shown in figure 84. Of interest in connection with studies of the water re$428271-57 \longrightarrow 2$ 

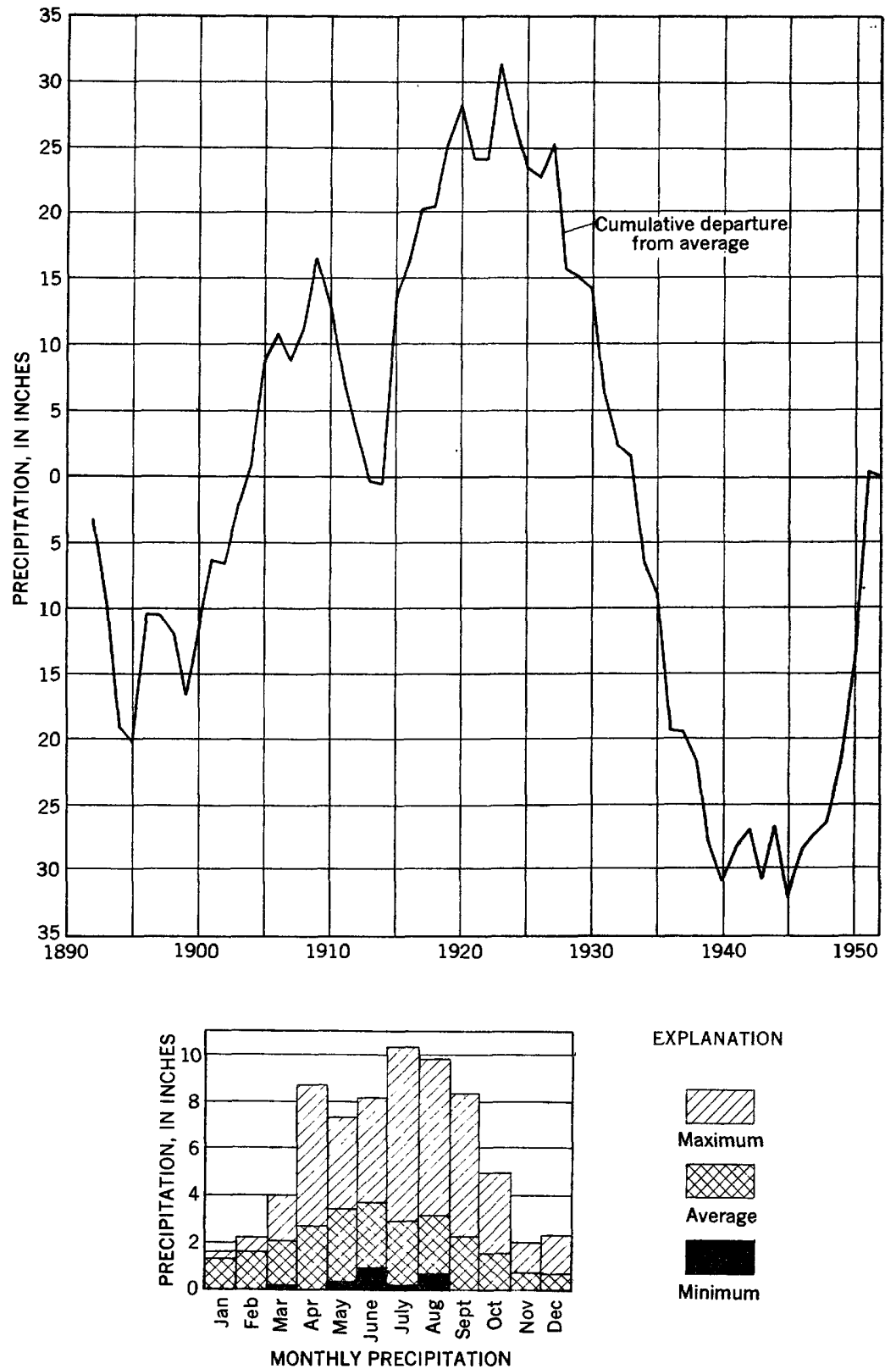

EXPLANATION

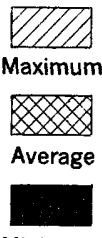

Minimum MONTHLY PRECIPITATION

FIGURE 84. -Maximum, minimum, and average monthly precipitation and cumulative departure from average annual precipitation at Ewing, Nebr., 1892-1952. 
sources of the basin is the long period, 1923-40, of successive years of below-average precipitation. Precipitation from 1940 to 1945 was about average, and it was continuously above average from 1945 to 1951. Because this study followed a 6-year period during which the cumulative total of above-average precipitation amounted to about 32 inches, the ground-water levels probably were at least at an average, long-term position during the study.

\section{TOPOGRAPHY AND DRATNAGE}

The Elkhorn River basin lies in the Great Plains physiographic province of the United States (Fenneman, 1931, p. 11-12). It is a nearly level to rolling constructional plain, which has been considerably modified by water and wind erosion. Nearly all the uplands slope gently southeastward. The basin includes parts of two rather welldefined physiographic divisions known as the Sand Hills and loess plains regions.

The western part of the basin is in the Sand Hills region of Nebraska. Here, wind has formed a gently undulating to hilly terrain in loose sand. The sand has been deposited in an irregular succession of hills and ridges, which range in height from 10 to 80 feet above the intervening valleys, pockets, and swales. The monotony of the landscape is broken in places by small lakes and marshes. The few, small, permanently flowing, rather sluggish and tortuous streams are entrenched to a depth of only 4 or 5 feet. An intricate system of scarcely perceptible swales slowly contributes water to the streams during and after early spring thaws and long periods of rainy weather.

The eastern part of the basin is within the loess plains region of the Great Plains province. The original surface has been modified considerably by erosion, and only a part remains to mark the level of the former loess mantle. The topography in this part of the basin is moderately to sharply rolling except on the broad, flat terraces and flood plains along the Elkhorn and North Branch of the Elkhorn Rivers and on the narrow alluvial lands along the larger creeks. An eroded loess plain lies south of the Elkhorn River valley. This plain is the highest part of the basin and is a remnant of the original loess plain. The topography ranges from almost flat to hilly; narrow strips of alluvial land occur along the creeks and small drainageways. The gradients of the larger streams generally are low, and the stream valleys are broad and shallow.

\section{STRATIGRAPHIC UNITS AND THEIR WATER-YIELDING PROPERTIES}

The rock formations exposed at the surface in the upper Elkhorn River basin are almost exclusively unconsolidated sedimentary rocks of Pleistocene or Recent age. These sedimentary rocks, which are 


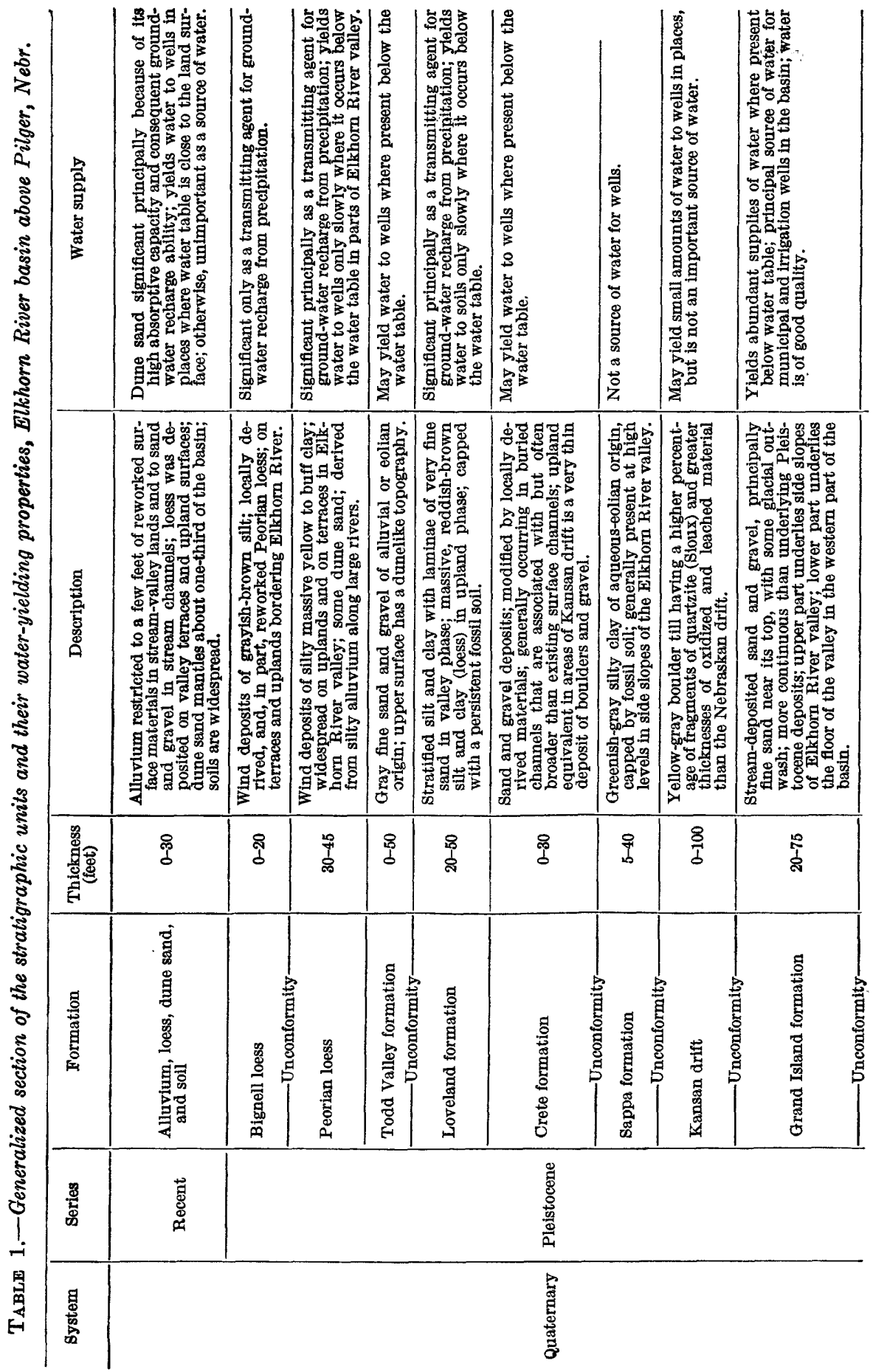


GROUND-WATER RESOURCES, ELKHORN RIVER BASIN, NEBRASKA 723

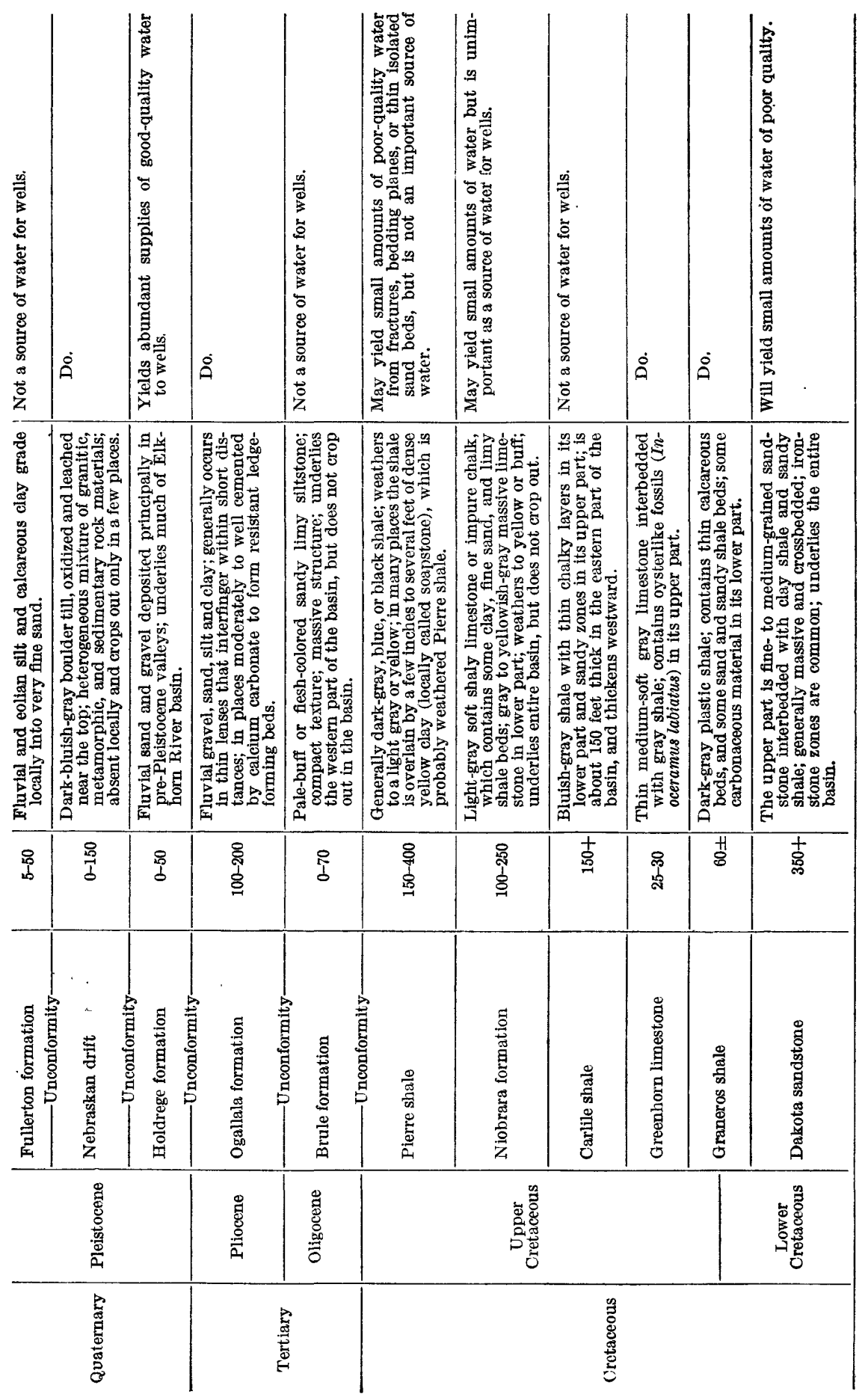


collectively known as mantle rock, comprise wind-blown loess and dune sand underlain by fluvial silt, sand, gravel, and clay deposits. The mantle rock rests on bedrock of Tertiary or Cretaceous age which is flat lying or only gently warped. The rocks of Tertiary age consist of thin, interfingering lenses of gravel, sand, silt, and clay, moderately to well cemented in some places, and the Cretaceous formations consist of alternating layers of sandstone, limestone, and shale. The formations and descriptions of their probable water-yielding properties are summarized in table 1 . Few wells in the basin reach bedrock; therefore, adequate tests of the water-bearing or water-yielding properties of the bedrock formations are not available.

\section{GROUND WATER}

\section{OCCURRENCE, SOURCE, AND MOVEMENT}

Ground water occurs in the basin in the pore spaces of the underlying materials. In most of the basin, ground water occurs under water-table conditions, but in some places it is confined under artesian pressure. Artesian flows have been reported locally from gravel beds at three different horizons in deposits of Pleistocene age. Typical is well 22-1-29bb (Madison County), which is an irrigation well obtaining water under sufficient pressure to flow at the rate of about 35 gallo;s per minute (gpm) at the land surface.

The depth to the water table ranges from a few feet to more than 100 feet below the land surface. The water table in the alluvium that underlies the flood plain of the streams generally is within 10 feet of the land surface.

Most precipitation upon the basin becomes surface runoff, is used by growing plants, or is evaporated. The remainder, a small percentage of the total, percolates to the water table as recharge to the ground-water reservoir.

Ground water moves from higher to lower altitudes in the direction of the hydraulic gradient, and if all other factors are constant, the rate of movement is proportional to the gradient. Generally, the direction of ground-water movement in the basin is toward the streams.

\section{GROUND-WATER REGIONS}

The Elkhorn River basin above Pilger, Nebr., includes three ground-water regions which have been defined by Condra and Reed (1936). They are the Sand Hills, the central, and the northern drift regions. (See fig. 85.)

\section{SAND HILIS REGION}

The water table in the Sand Hills region is in most places less than 20 feet below the land surface, and the ground-water reservoir is 


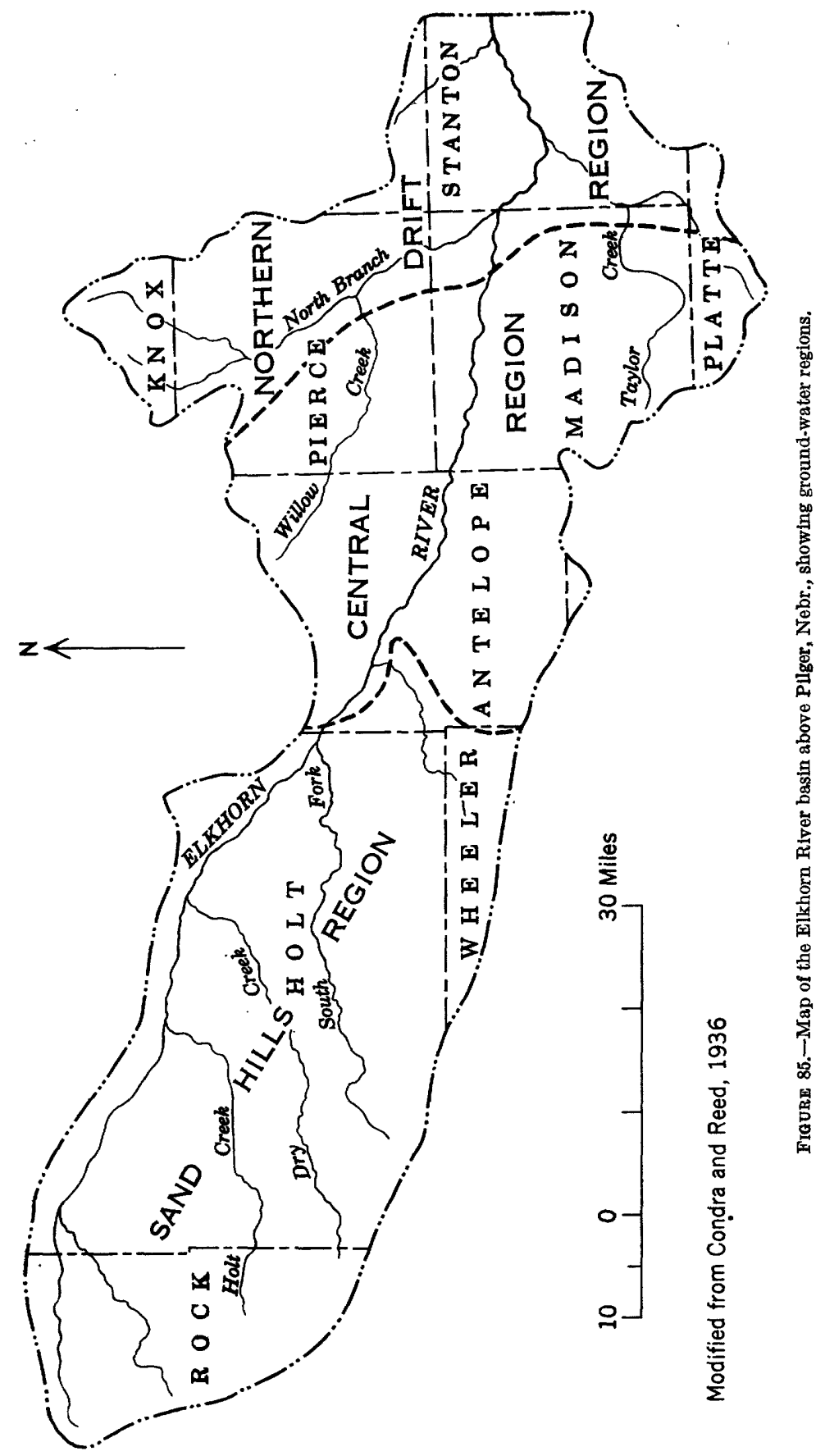


readily replenished by infiltration from precipitation. The Brule formation and the Pierre shale are nearly impervious and are overlain by permeable sands of Tertiary and Pleistocene age, uppermost of which is dune sand. In places, the saturated thickness of the sands is 300-500 feet. The general direction of ground-water movement is southeastward, but locally south of the Elkhorn River, it is northeastward toward the river. Many artesian wells, which range in depth between 80 and 300 feet, obtain water from formations of the Quaternary system in the eastern part of the Sand Hills region. The deposits of Pleistocene and Tertiary age would yield water to irrigation wells in this region, but irrigation farming is restricted because removal of the sod by plowing subjects the sandy soil to destructive wind erosion. A few stockraisers now irrigate feed crops in some parts of the Sand Hills, and ranching in the basin eventually may be supplemented with considerable irrigation farming.

\section{CENTRAL REgION}

The topography of the central region, which lies between the Sand Hills and northern drift regions, is smooth to rough. The surficial deposits in this region consist of loess, which is underlai I by deposits of silt, sand, and gravel of Pleistocene age that rest in most places upon the Ogallala formation of Pliocene age. The Ogallala formation thins toward the east and in some localities in the region was removed by erosion before the Pleistocene epoch. In these places, the deposits of Pleistocene age rest on almost impervious bedrock of Cretaceous age, which underlies the entire basin. Ground-water recharge is received from local rainfall, from general southeastward underflow from the Sand Hills, and from streams that originate in the Sand Hills region. Wells obtain water from sand or gravel at depths ranging from 100 to 200 feet in the uplands, and at relatively shallow depths in the valleys. Prospects for the development of ground water for irrigation in this region are good, as the ground-water storage is extensive and the water is of good quality.

\section{NORTHERN DRIFT REGION}

The surficial deposits in the northern drift region are loess and alluvium which mantle glacial till. The till is intercalated with stratified drift of sand and gravel, which is above the water table along some of the bluffs and valley margins. Most wells obtain water from the alluvium or the drift, but where water is not available from these deposits, wells are drilled to the Dakota sandstone. The wells range in depth from about 100 feet or more in the eastern part of the region to 800 feet in the northwestern part. The potentialities for irrigation development in some parts of the region are good. 


\section{FL̈UCTUATIONS OF THE WATER TABLE}

The water table fluctuates with changes in the rates of recharge and discharge. If the discharge from a ground-water reservoir exceeds the recharge, the water table will decline; if recharge exceeds discharge, the water table will rise. Thus, the rate and magnitude of fluctuation of the water table depend upon the rate and magnitude at which the ground-water reservoir is replenished or depleted. A ground-water reservoir is in equilibrium when the recharge equals discharge.

Long-term periodic.water-level measurements have been made in five observation wells in the basin. (See fig. 86.) Short-term periodic measurements of the depth to water in nine other wells in the basin are also available. (See fig. 87.) The effects on the water table of recharge to and discharge from the ground-water reservoir are apparent from the hydrographs. The water table is seldom stationary; thus, periodic water-level measurements in wells over a long period are necessary to understand fully the nature of changes in storage in the ground-water reservoir.

Most of the wells whose hydrographs are shown in figure 86 are close to streams, and the major, sharp rises of the water level in the wells reflect corresponding rises in the stage of a nearby stream during high surface-water runoff following heavy precipitation or snowmelt.

An annual rise of water level, sometimes of several feet, in response to seasonal precipitation is apparent in the hydrographs of most of the wells. Extended periods of drought or above-average precipitation also are reflected in the long-term hydrographs. For example, the period of successive years of above-average precipitation beginning in 1945 (see fig. 84) is apparently reflected by a general rise of the water level in well 27-9-34da beginning during 1948 and 1949 (see fig. 86). The hydrographs of figure 86 indicate that there has been no long-term decline of the water table in the basin and that the watex table has fluctuated principally in response to changes in infiltration from precipitation.

\section{GROUND-WATER DISCHARGE}

\section{EVAPOTRANSPIRATION}

Ground water is withdrawn from the zone of saturation by evaporation in places where the capillary fringe extends to the land surface. The water surfaces of some lakes in the Sand Hills region are essentially an extension of the water table, and much of the water loss from those lakes is ground-water discharge. Ground water is discharged. also by transpiration from plants in places where the plant roots can obtain water from the capillary fringe. 


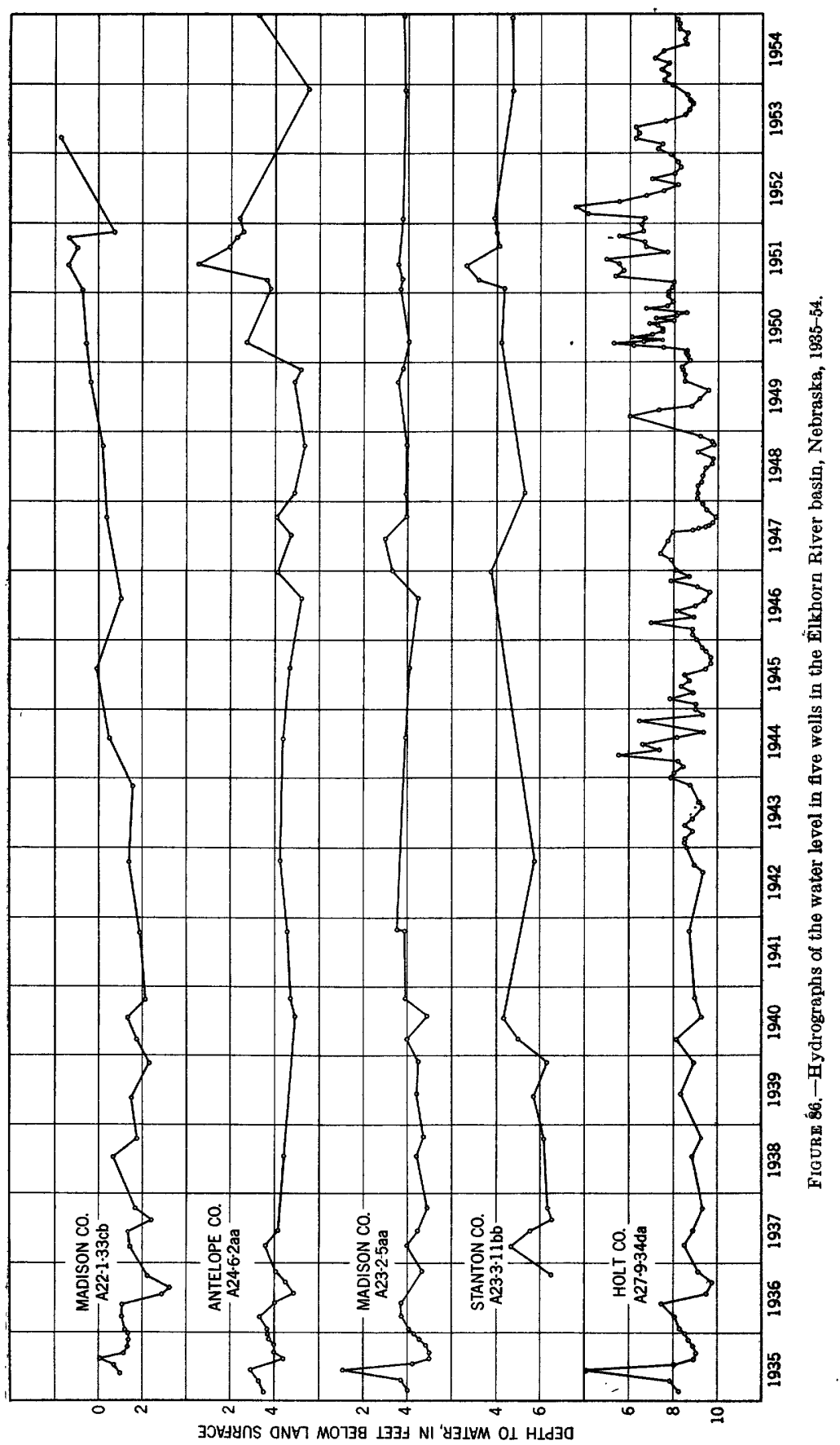



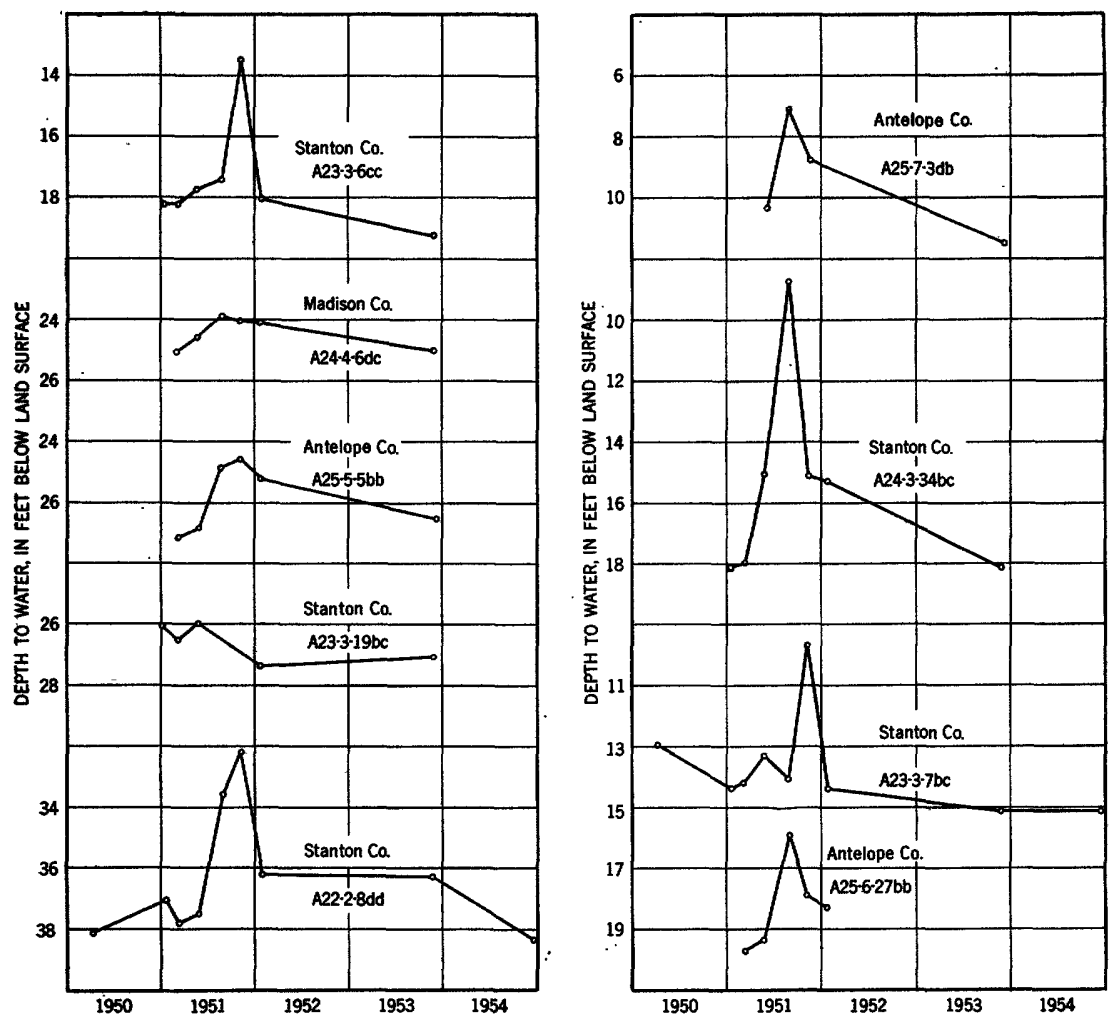

FIGURE 87.-Hydrographs of the water level in nine wells in the Elkhorn River basin, Nebraska, 1950-54,

The amount of ground water discharged by evapotranspiration varies with a number of factors, such as air and soil temperature, relative humidity, wind velocity, and season; the rate of evapotranspiration is greatest during the plant-growth season when temperatures are highest. Although this study was not designed to determine the quantity of ground water discharged by evapotranspiration, the quantity so discharged is known to be considerable from the parts of the area in which the water table is close to the land surface.

\section{SEEPAGE INTO STREAMS}

Considerable ground water leaves the Elkhorn River basin above Pilger, Nebr., in the form of streamflow in the Elkhorn River. Because of the absorptive character of the soils in the basin, especially in the Sand Hills region, a relatively large part of the precipitation on the basin infiltrates into the soil, and runoff over the land surface occurs only after periods of exceptionally heavy rainfall. This is verified by field observation and by comparison of the daily discharge of the Elkhorn River at the Norfolk, Nebr., stream-gaging station 
with the daily precipitation. Consequently, the flow in the Elkhorn River is more uniform than that in streams draining areas having high surface runoff rates.

Much of the annual streamflow in the Elkhorn River at Norfolk represents water discharged from the ground-water reservoir above Norfolk. The amount of ground water thus discharged from the basin is considerable, as can be inferred from the following table:

Annual discharge of Elkhorn River near Norfolk, Nebr., 1946-52

[From records of U. S. Geol. Survey and Nebr. Dept. of Roads and Irrigation]

Water year

Total discharge,

1946 208,500

1947 568,100

1948 248,090

1949 569,390

1950 524,370

1951 860,400

1952

677,340

UNDERFLOW

A considerable amount of ground water is believed to pass beyond the Elkhorn River basin above Pilger, Nebr., by natural ground-water movement down the water-table gradient and through the aquifers that underlie the eastern boundary of the basin. Ground water that is neither intercepted by seepage into streams and drains nor discharged by evapotranspiration or pumping continues to move southeastward and out of the basin. The quantity of the underflow was not determined.

\section{WITHDRAWALS FROM WFLLS}

Ground water is pumped from many domestic and stock wells, from a few municipal wells, and from a few irrigation wells during the periods ot low precipitation that occur during the growing season. However, no attempt was made to determine the total annual withdrawal of ground water for irrigation and other purposes. The total quantity of water pumped is very small in proportion to the total amount of ground water available in the basin.

All public supply and irrigation wells in the basin, but only a few of the domestic and stock wells, were inventoried. Forty-two of the forty-five irrigation wells obtain water from sand and gravel of Pleistocene age; three obtain water from both sand and gravel of Pleistocene age and the Ogallala formation of Tertiary age. Table 6 shows the data collected during the well inventory; all tabulated wells are drilled wells with metal casing unless otherwise noted.

\section{DOMESTIC AND LIVESTOCK WATER SUPPLIES}

Most of the domestic and stock-water supplies in the Elkhorn River basin are obtained from wells. A few cisterns are used to store rain- 
water for laundry and other domestic purposes. The domestic and stock wells generally are driven or drilled wells of small diameter, are equipped with pitcher, force, rotary, or jet pumps, and are powered by hand, wind, or electricity. The wells discharge only a few gallons per minute. Much more water is pumped for domestic and stock use in the basin than for all other purposes.

\section{MUNICIPAL WATER SUPPLIES}

Twenty-six towns in the Elkhorn River basin above Pilger obtain water from wells. All towns in the basin have public water-supply systems except Amelia, which is supplied by privately owned artesian wells. Each home in Amelia has a flowing well, which is allowed to flow continuously and thus wasting much of the water. The wells in this town are about 100 feet deep, obtain water from sand and gravel of Pleistocene age, and produce a maximum of about $10 \mathrm{gpm}$ from any individual well. Records of municipal wells are given in tables 2 and 6.

TABLE 2.-Municipal water supplies

[See table 6 for additional data]

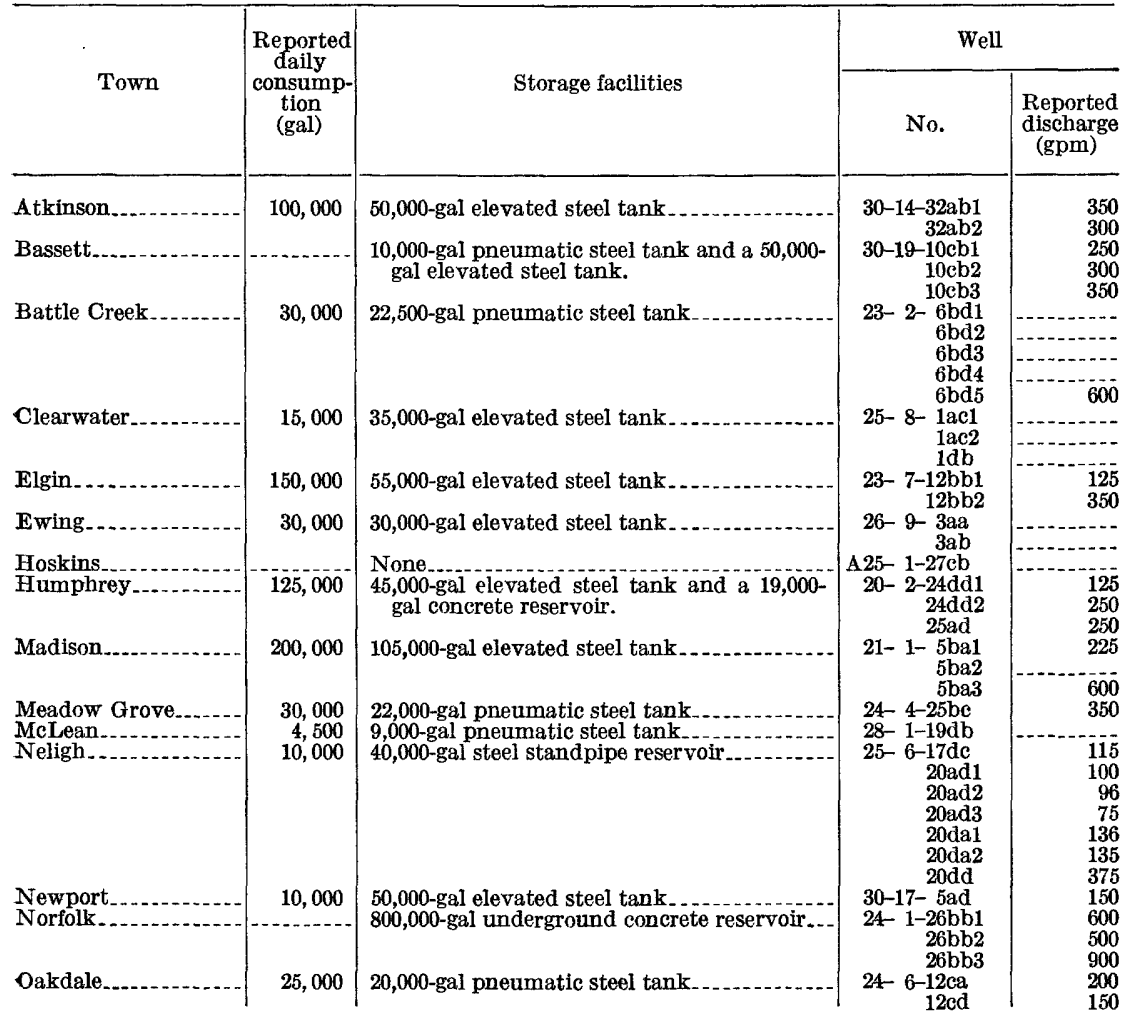


TABLE 2.-Municipal water supplies-Continued

[See table 6 for additional data]

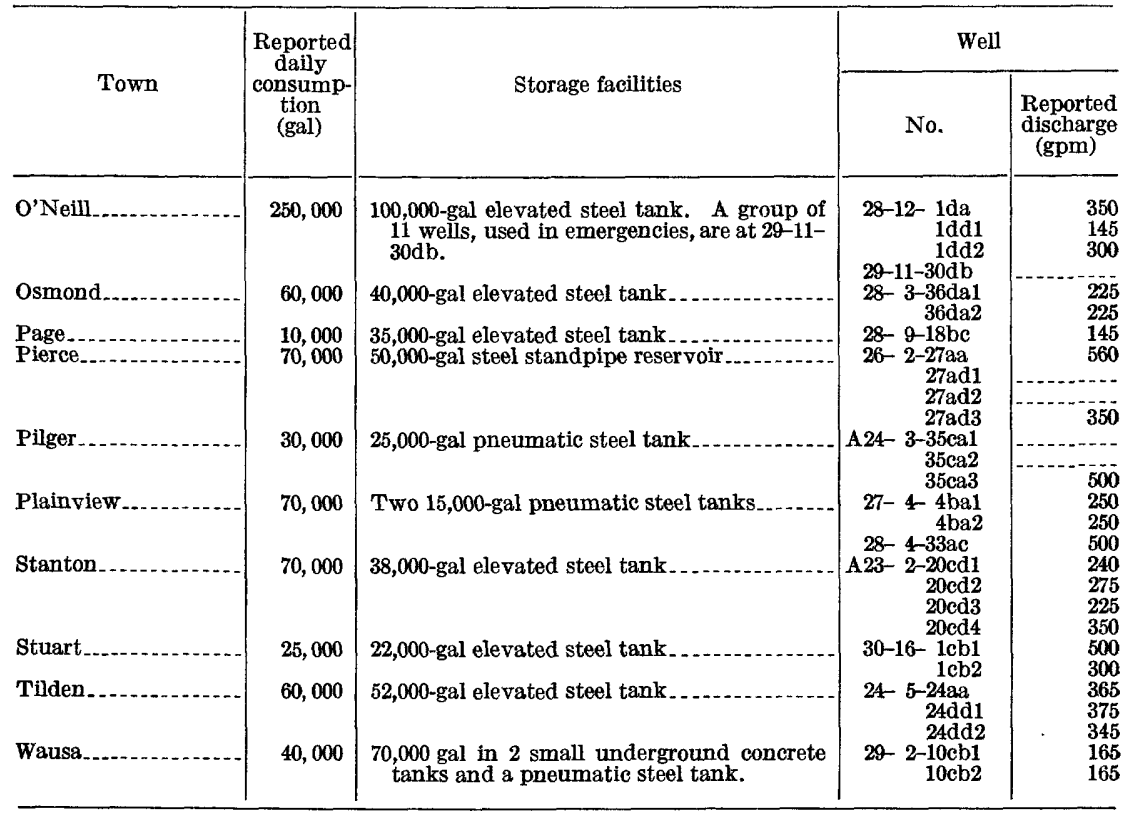

INDUSTRIAL WATER SUPPIIES

The use of ground water for industrial purposes is negligible. Railroads have changed from steam to diesel power, and their water use has been reduced greatly. Several creameries use relatively large amounts of water, which they purchase from local municipalities.

\section{IRRIGATION WATER SUPPIIES}

Ground water is the source of nearly all irrigation water used in the Elkhorn River basin above Pilger, Nebr. A few irrigators pump water directly from the Elkhorn River, but they have relatively small installations that pump only a very small percentage of the total amount of irrigation water. The irrigation wells are not pumped during years of favorable rainfall; irrigation generally is practiced only when the summer precipitation is decidedly deficient.

\section{POTENTIAI GROUND-WATER DEVELOPMENT}

Much more ground water than is at present (1953) developed could be pumped from the ground-water reservoir in the Elkhorn River basin above Pilger, Nebr., without seriously depleting the supply. Withdrawal of water from the ground-water reservoir will lower the water table, but to salvage ground water that is naturally discharged from the basin, the water table must necessarily be lowered. 
In the Sand Hills region, where ground-water levels are naturally high, pumping of consequence would lower the water table and create storage to accommodate additional ground-water recharge. Thus, some of the water that now runs off the land surface and into the streams would infiltrate the ground and be stored in a natural underground reservoir for future beneficial use. In addition, all or some of the water now evaporated from ponds and wet meadows and transpired by vegetation in places where the water table is close to the land surface would be salvaged. If the increased withdrawals of ground water by pumping exceed the amount of water salvaged from evapotranspiration losses, the water table will decline, and ultimately the ground-water discharge into the streams will diminish. However, that diminution of streamflow generally would not be appreciable before a considerable lapse of time, perhaps of tens of years. Should the quantity of water removed by pumping exceed the present base flow in the streams plus the present evapotranspiration losses, the water table would decline progressively. However, the water table would rise during years of above-normal precipitation and, if the precipitation was unusually great, could well be restored to its initial position temporarily. The available water in the basin can be conserved and utilized best only by periodically lowering the water table and thus salvaging water that now flows out of the basin, is evaporated, or is nonbeneficially transpired.

Detailed ground-water studies are needed before and during extensive development of ground water for irrigation in the basin to determine the perennial safe yield of the ground-water reservoir. The studies would require adequate topographic maps; construction of water-table contour maps; long-term periodic water-level measurements in observation wells; geologic mapping; construction of maps showing the depth to water and the saturated thickness of the aquifier; determination of the transmissibility and storage coefficients of the aquifers; additional test drilling; continuation and perhaps intensification of streamflow measurements; and adequate determination of the chemical quality of the water and ultimate changes in that quality. A detailed appraisal of ground-water conditions in the relatively undeveloped areas is particularly essential.

\section{CHEMICAL QUALITY OF THE WATER}

\section{By Robert A. Krieger}

Results of chemical analysis of 29 samples of ground water from Quaternary deposits in the upper Elkhorn River basin are given in table 3. Eight of these samples were collected during the 1952 field season, especially for this report. The location of the wells that were 


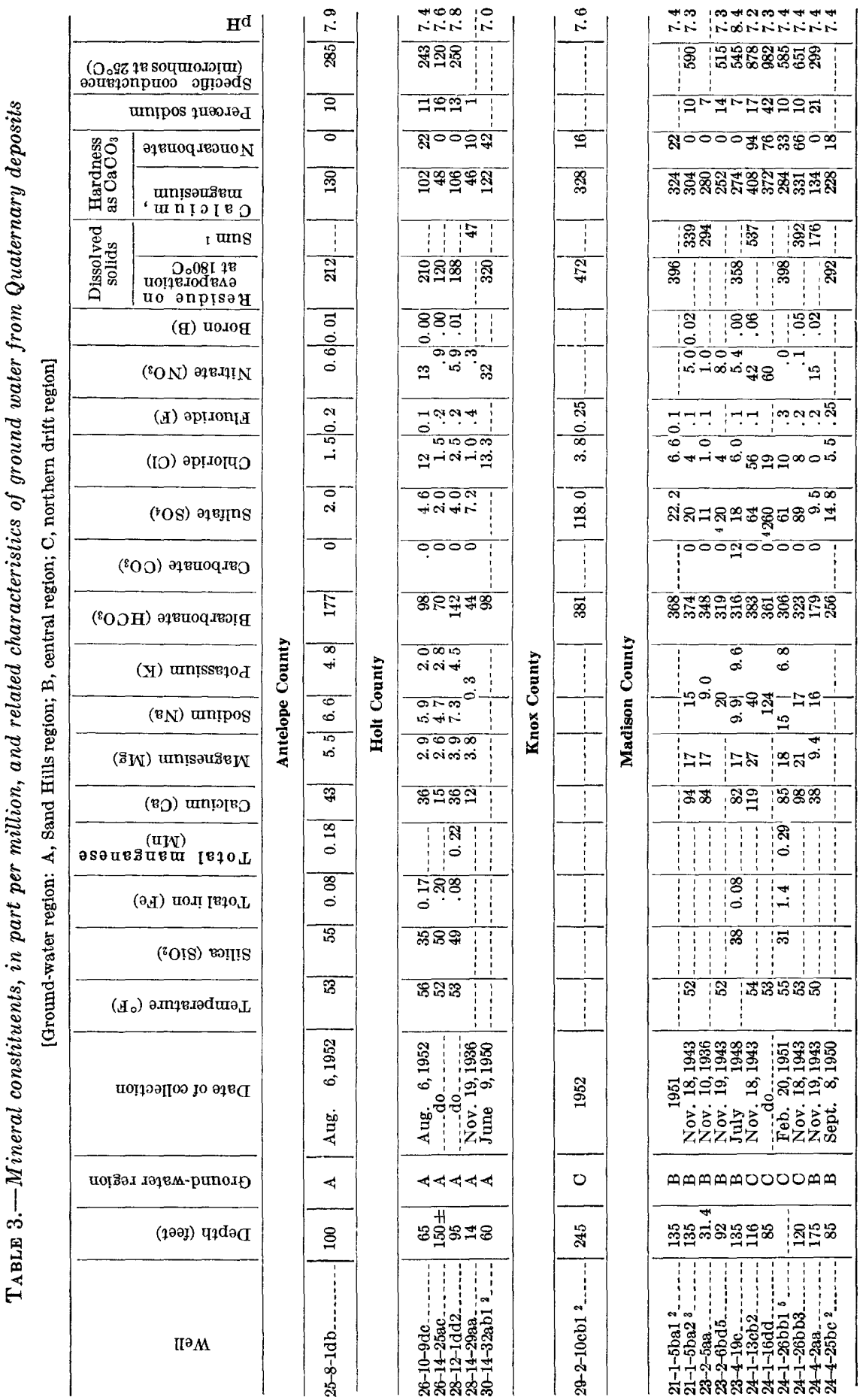




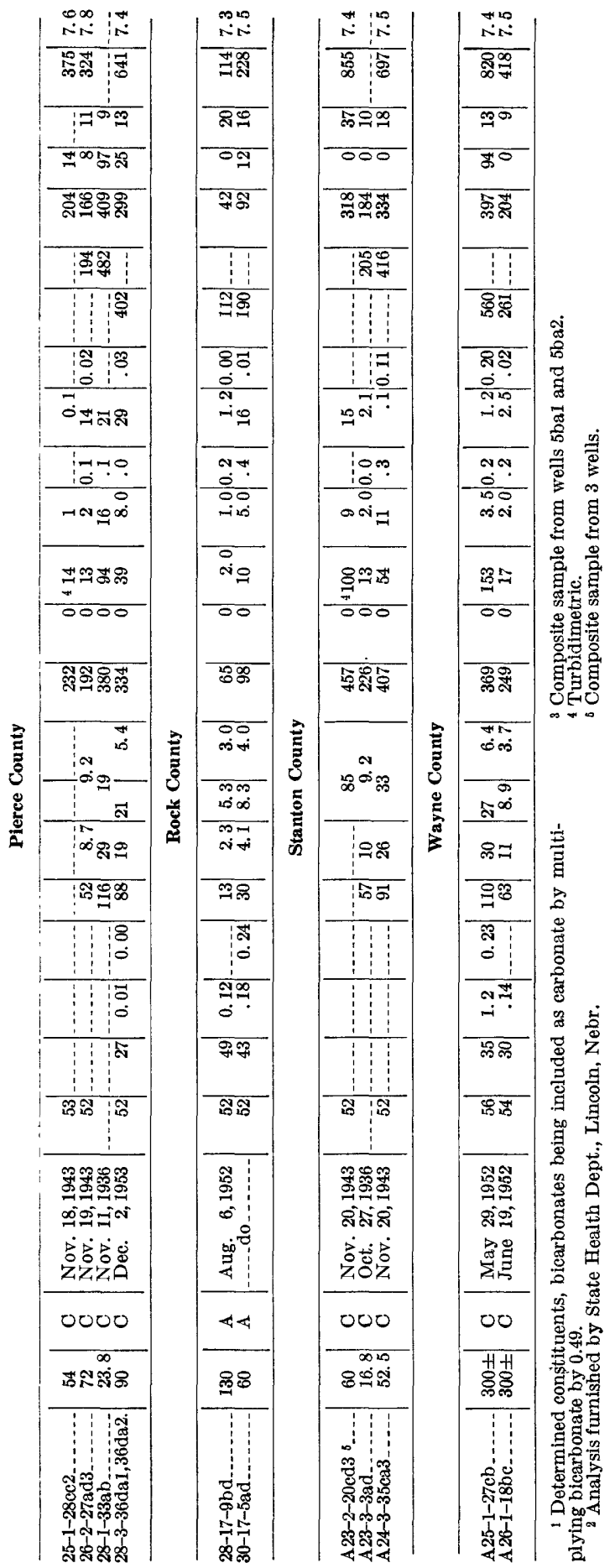


sampled is shown on plate 44. The results of chemical analysis of 14 samples collected from the Elkhorn River and its major tributaries from 1943 to 1950 are given in table 4.

Ground water is progressively more mineralized toward the eastern part of the basin, as shown in the table below. In the Sand Hills region (see fig. 85), the water is typically low in total mineralization, hardness, and percent sodium. In the central region the water is more mineralized and harder and has larger amounts of bicarbonate in solution. In the northern drift region the water is considerably more mineralized and contains significantly higher concentrations of sodium and sulfate. Water in the northern drift region is more highly mineralized than that in the other regions because the mantle rock in the northern drift region contains larger proportions of easily weathered and soluble minerals.

\begin{tabular}{|c|c|c|c|c|c|c|}
\hline \multirow{2}{*}{ Constituent or property } & \multicolumn{2}{|c|}{ Sand Hills region } & \multicolumn{2}{|c|}{ Central region } & \multicolumn{2}{|c|}{ Northern drift region } \\
\hline & Maximum & Minimum & Maximum & Minimum & Maximum & Minimum \\
\hline $\begin{array}{l}\text { Specific conductance in mi- } \\
\text { cromhos at } 25^{\circ} \mathrm{C}\end{array}$ & 285 & 114 & 590 & 299 & 982 & 324 \\
\hline 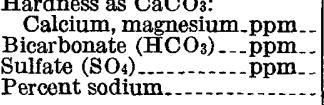 & $\begin{array}{r}130 \\
177 \\
10 \\
20\end{array}$ & $\begin{array}{c}42 \\
\mathbf{4 4} \\
2.0 \\
1\end{array}$ & $\begin{array}{l}324 \\
374 \\
22.2 \\
21\end{array}$ & $\begin{array}{l}134 \\
179 \\
9.5 \\
7\end{array}$ & $\begin{array}{r}409 \\
457 \\
260 \\
42\end{array}$ & $\begin{array}{r}166 \\
192 \\
13 \\
9\end{array}$ \\
\hline
\end{tabular}

Water in the main stem and in South Fork is similar in chemical quality to the ground water of the Sand Hills region. (See table 4.) Most of the drainage basin of the North Branch is in the northern drift region (see fig. 85 and pl. 44); and the water in the North Branch is similar in quality to the ground water in the central and northern drift regions.

\section{CHEMICAL QUALITY OF THE WATER IN RELATION TO USE}

The chemical quality of irrigation water is important because the dissolved salts or other chemical or physical characteristics may result in injury to plants and soils. For example, plant growth may be impaired by high total salinity or high boron concentration; soil permeability and tilth may be impaired if sodium is the major cation in the water, particularly if there is a high ratio of sodium to other cations; or alkaline soils may develop if sodium bicarbonate is the predominant dissolved salt.

Criteria for classifying irrigation water have been based by the United States Salinity Laboratory Staff (1954, p. 69-82) on average 
conditions of drainage, infiltration rate, quantity of water used, soil texture, climate, and salt tolerance of plants.

Water is classified as "low-salinity water" if the specific conductance is less than 250 micromhos, as "medium-salinity water" if from 250 to 750 micromhos, and as "high-salinity water" if from 750 to 2,250 micromhos. The terms are explained by the U.S. Salinity Laboratory Staff (1954) as-

Low-salinity water can be used for irrigation with most crops on most soils with little likelihood that soil salinity will develop. Some leaching is required, but this occurs under normal irrigation practices except in soils of extremely low permeability. Medium-salinity water can be used if a moderate amount of leaching occurs. Plants with moderate salt tolerance can be grown in most cases without special practices for salinity control. High-salinity water cannot be used on soils with restricted drainage. Even with adequate drainage, special management for salinity control may be required and plants with good salt tolerance should be selected.

The ground water has low to medium salinity in the Sand Hills region, medium salinity in the central region, and medium to high salinity in the northern drift region. Water in the Elkhorn River and its tributaries has low to medium salinity. Thus, in the central and northern drift regions, ground water should be used for irrigation only on soils that have good drainage. Most crops now grown in the basin have medium or high salt tolerances. Only fruit trees, a few vegetable crops, field beans, and some varieties of clover have low salt tolerance.

Concentrations of boron in water of the basin were less than 0.33 ppm, which is not considered injurious in irrigation water to even the most boron-sensitive plants. Because the water contains only minor amounts of sodium, soil permeability and tilth would not be impaired.

If irrigation water contains more carbonate and bicarbonate than calcium and magnesium, then, after evaporation and plant uptake have resulted in precipitation of calcium and magnesium carbonate, the residue of carbonate in the soil solution is paired with sodium (Eaton, 1950). This sodium carbonate in solution is "residual sodium carbonate"; it normally increases the $\mathrm{pH}$ of the soil solution and may ultimately cause the formation of black-alkali soils. However, both ground and surface waters in the basin have less than the usually accepted threshold value of $1.25 \mathrm{epm}$ (equivalents per million) of "residual sodium carbonate" and thus are suitable for irrigation.

The drinking-water standards of the United States Public Health Service (1946) for water used on interstate common carriers are accepted by the American Water Works Association as standards for public supplies. Although these standards are not compulsory for water that is used locally, they are measures of the suitability of 


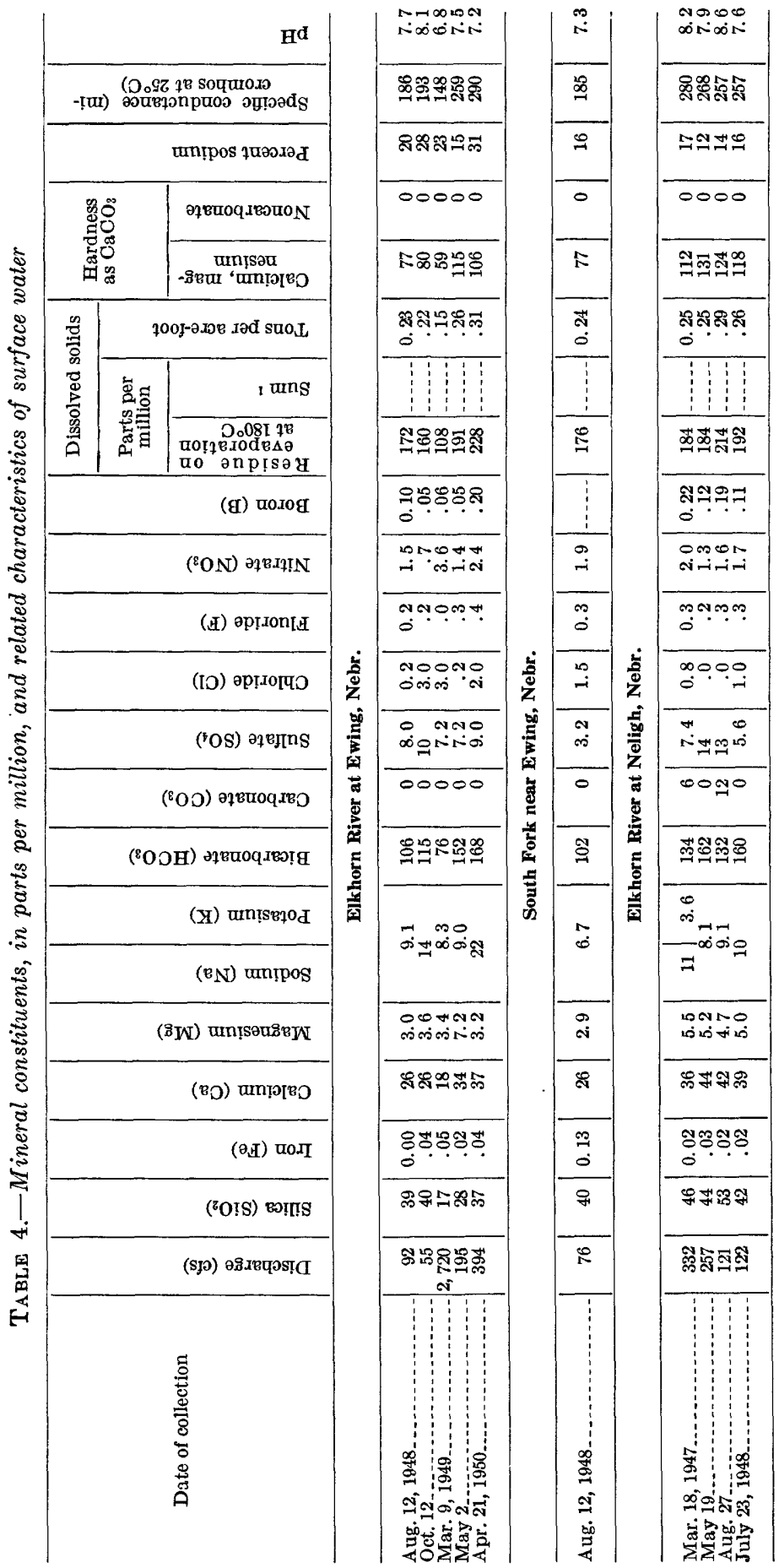


GROUND-WATER RESOURCES, ELKHORN RIVER BASIN, NEBRASKA 739

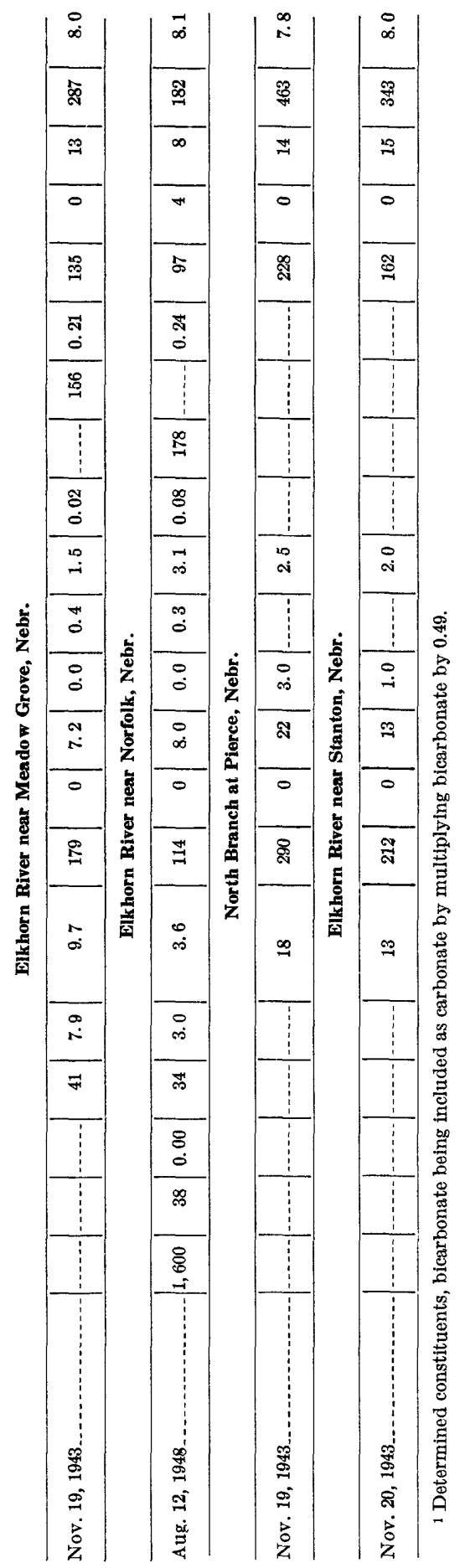


water for domestic use. These standards for some chemical characteristics of water are as follows:

Maximum

concentra-

tion limits

(parts per

million)

Iron and manganese $(\mathrm{Fe}+\mathrm{Mn})$

0. 3

Magnesium $(\mathrm{Mg})$

125

Sulfate $\left(\mathrm{SO}_{4}\right)$

250

Chloride $(\mathrm{Cl})$ 250

Fluoride (F)

Nitrate $\left(\mathrm{NO}_{3}\right)$

144

Dissolved solids

2500

1 Maxcy, 1950 .

$21,000 \mathrm{ppm}$ permissible when water of better quality is not available.

Except for excessive concentrations of iron and manganese in water from some wells, the limiting concentrations generally were not exceeded in the ground and surface waters of the basin. However, ground water in the central and northern drift regions is harder than is usually recommended for domestic use, and its treatment to reduce hardness may be desirable. Specific limits of hardness cannot be set, but the following are general criteria:

Hardness as $\mathrm{CaCO}_{3}$ (ppm) $<60$ $60-120$

$120-200$ $>200$

Water in the Sand Hills region is the most suitable, and water in the northern drift region is the least suitable for domestic use.

\section{LOGS OF TEST HOLES AND WELLS}

The logs of 36 test holes and wells are shown in numerical order, by counties, in table 5. The logs of test holes 25-4-27db (Pierce County), 23-3-30ab, and 23-4-35aa (Madison County) were prepared by V. H. Dreeszen of the Conservation and Survey Division, University of Nebraska, from samples of drill cuttings submitted to the Nebraska Geological Survey by the drillers. Logs of other test holes or wells were obtained from the well owner or from drillers. 
TABLE 5.-Logs of test holes and wells, Elkhorn River basin, Nebraska

$\left|\begin{array}{c}\begin{array}{c}\text { Thick- } \\
\text { ness } \\
\text { (feet) }\end{array} \\
\text { (feet) }\end{array}\right|$\begin{tabular}{c|c} 
Depth \\
(feet)
\end{tabular} \mid $\begin{gathered}\text { Thick- Depth } \\
\text { (feet) } \\
\text { (fess }\end{gathered}$

\section{ANTELOPE COUNTY}

Well 23-6-8da. Ben Heithoff

\begin{tabular}{|c|c|c|c|c|c|}
\hline $\begin{array}{l}\text { Soil. } \\
\text { Clay, sandy } \\
\text { Clay, } \\
\text { Sand, }\end{array}$ & $\begin{array}{r}52 \\
53 \\
7 \\
3\end{array}$ & $\begin{array}{r}52 \\
105 \\
112 \\
115\end{array}$ & $\begin{array}{l}\text { Clay, } \\
\text { Sand, some clay } \\
\text { Sand, coarse } \\
\text { Gravel }\end{array}$ & $\begin{array}{r}5 \\
2 \\
26 \\
60\end{array}$ & $\begin{array}{l}120 \\
122 \\
148 \\
208\end{array}$ \\
\hline
\end{tabular}

Well 23-7-23bc. W. C. Schulte

\begin{tabular}{|c|c|c|c|c|c|}
\hline $\begin{array}{l}\text { Clay, } \\
\text { Sand and clay } \\
\text { Clay and sand } \\
\text { Clay, sandy } \\
\text { Sand }\end{array}$ & $\begin{array}{r}58 \\
26 \\
4 \\
2 \\
30 \\
4\end{array}$ & $\begin{array}{r}58 \\
84 \\
88 \\
90 \\
120 \\
124\end{array}$ & $\begin{array}{l}\text { Clay, sandy } \\
\text { Sand } \\
\text { Clay, sandy } \\
\text { Sand } \\
\text { Gravel }\end{array}$ & $\begin{array}{r}12 \\
6 \\
24 \\
4 \\
72\end{array}$ & $\begin{array}{l}136 \\
142 \\
166 \\
170 \\
242\end{array}$ \\
\hline
\end{tabular}

Well 24-5-3bb. Joe Wittwer

\begin{tabular}{|c|c|c|c|c|c|}
\hline $\begin{array}{l}\text { Soil } \\
\text { Sand } \\
\text { Clay, sandy }\end{array}$ & $\begin{array}{l}38 \\
12 \\
18 \\
10\end{array}$ & $\begin{array}{l}38 \\
50 \\
68 \\
78\end{array}$ & $\begin{array}{l}\text { Clay, sandy } \\
\text { Sand, } \\
\text { Clay, sandy }\end{array}$ & $\begin{array}{r}57 \\
27 \\
9 \\
30\end{array}$ & $\begin{array}{l}135 \\
162 \\
171 \\
201\end{array}$ \\
\hline
\end{tabular}

Well 24-5-5ab. Lewis Evans

\begin{tabular}{|c|c|c|c|c|c|}
\hline $\begin{array}{l}\text { Soll } \\
\text { Clay, blue } \\
\text { Gravel } \\
\text { Limestone. }\end{array}$ & $\begin{array}{r}40 \\
5 \\
31 \\
1\end{array}$ & $\begin{array}{l}40 \\
45 \\
76 \\
77\end{array}$ & $\begin{array}{l}\text { Sand } \\
\text { Clay, with some limestone. }\end{array}$ & $\begin{array}{l}22 \\
49 \\
58\end{array}$ & $\begin{array}{r}99 \\
148 \\
206\end{array}$ \\
\hline
\end{tabular}

Test hole 24-5-5bb2

\begin{tabular}{|c|c|c|c|c|c|}
\hline $\begin{array}{l}\text { Soil } \\
\text { Sand and gravel } \\
\text { Clay, sandy }\end{array}$ & $\begin{array}{r}41 \\
23 \\
5\end{array}$ & $\begin{array}{l}41 \\
64 \\
69\end{array}$ & Sand, sandy & $\begin{array}{l}16 \\
40\end{array}$ & $\begin{array}{r}85 \\
125\end{array}$ \\
\hline \multicolumn{6}{|c|}{ Test hole $24-5-5 \mathrm{bb3}$} \\
\hline $\begin{array}{l}\text { Soil } \\
\text { Sand, coarse. } \\
\text { Gravel............. }\end{array}$ & $\begin{array}{r}36 \\
6 \\
24\end{array}$ & $\begin{array}{l}36 \\
42 \\
66\end{array}$ & Slayd and clay & $\begin{array}{r}6 \\
30\end{array}$ & $\begin{array}{r}72 \\
102\end{array}$ \\
\hline \multicolumn{6}{|c|}{ Well 24-5-5cb. Pete-Mhrtensin } \\
\hline $\begin{array}{l}\text { Soll. } \\
\text { Clay, biue } \\
\text { Sand, coarse.... } \\
\text { Sand and gravel. } \\
\text { Sand }\end{array}$ & $\begin{array}{r}16 \\
8 \\
8 \\
22 \\
11\end{array}$ & $\begin{array}{l}16 \\
24 \\
32 \\
54 \\
65\end{array}$ & $\begin{array}{l}\text { Sand, coarse. } \\
\text { Sand, fine } \\
\text { Gravel } \\
\text { Sandstone. } \\
\text { Clay }\end{array}$ & $\begin{array}{r}5 \\
5 \\
12 \\
9 \\
14\end{array}$ & $\begin{array}{r}70 \\
75 \\
87 \\
96 \\
110\end{array}$ \\
\hline \multicolumn{6}{|c|}{ Well 24-5-9bd. } \\
\hline $\begin{array}{l}\text { Soil } \\
\text { Sand, fine; some clay } \\
\text { Clay, } \\
\text { Sand...... }\end{array}$ & $\begin{array}{r}7 \\
1 \\
11 \\
46\end{array}$ & $\begin{array}{r}7 \\
8 \\
19 \\
65\end{array}$ & $\begin{array}{l}\text { Clay, blue } \\
\text { Gravel, coarse } \\
\text { Limestone. }\end{array}$ & $\begin{array}{r}2 \\
18 \\
2\end{array}$ & $\begin{array}{l}67 \\
85 \\
87\end{array}$ \\
\hline
\end{tabular}


TABLE 5.-Logs of test holes and wells, Elkhorn River basin, Nebraska-Continued

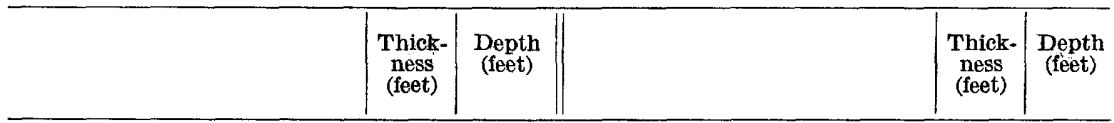

ANTELOPE COUNTY-Continned

Well 24-5-24aa. City of Tilden

\begin{tabular}{|c|c|c|c|c|c|}
\hline Soll___. & 5 & 5 & Sand, very fine, loose & 20 & 57 \\
\hline Clay and sand. & 5 & 10 & Sand, very fine; some clay ....... & 6 & 63 \\
\hline Sand, very fine, loose. & $\mathbf{5}$ & 15 & Sand, coarse & 8 & 71 \\
\hline Sand, very fine, compact & 13 & 28 & Sand, very fine, compact. & 5 & 76 \\
\hline Clay, blue. & 5 & 33 & Sand, coarse & 9 & 85 \\
\hline Sand, very fine, compact. & 4 & 37 & Sand and gravel & 4 & 89 \\
\hline
\end{tabular}

Test hole 24-5-34ce

\begin{tabular}{|c|c|c|c|c|c|}
\hline Soil_..... & 4 & 4 & Sand, fine $\ldots \ldots$ & 23 & 81 \\
\hline Gravel. & 4 & 8 & Clay & 4 & 85 \\
\hline 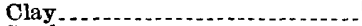 & 7 & 15 & Sand. & $\overline{\mathbf{5}}$ & 90 \\
\hline Sand & 6 & 21 & Clay & 22 & 112 \\
\hline 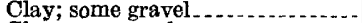 & 10 & 31 & Sand & 22 & 134 \\
\hline Clay; some sand . . . . & 9 & 40 & Clay & 8 & 142 \\
\hline Clay . & 18 & 58 & Sand & 43 & 185 \\
\hline
\end{tabular}

Well 25-6-20adl. City of Neligh

\begin{tabular}{|c|c|c|c|c|c|}
\hline $\begin{array}{l}\text { Clay, yellow: } \\
\text { Clay, black } \\
\text { Clay, yellow } \\
\text { Sand, } \\
\text { Sand, fine. }\end{array}$ & $\begin{array}{r}11 \\
2 \\
2 \\
1 \\
2\end{array}$ & $\begin{array}{l}11 \\
13 \\
15 \\
16 \\
18\end{array}$ & $\begin{array}{l}\text { Sand, very fine. } \\
\text { Sand, coarse } \\
\text { Sand, very fine, } \\
\text { Sand and gravel. }\end{array}$ & $\begin{array}{l}2 \\
5 \\
4 \\
5\end{array}$ & $\begin{array}{l}20 \\
25 \\
29 \\
34\end{array}$ \\
\hline
\end{tabular}

Well 25-6-20ad2. City of Neligh

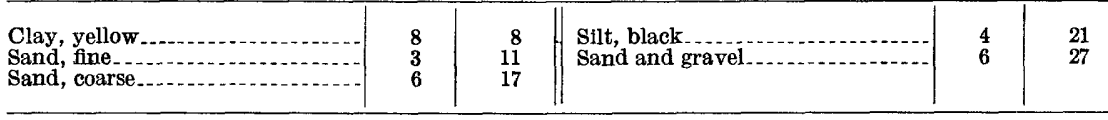

\section{Well 25-6-20ad3. City of Neligh}

\begin{tabular}{|c|c|c|c|c|c|}
\hline Soil & $\begin{array}{l}3 \\
7\end{array}$ & $\begin{array}{r}3 \\
10\end{array}$ & $\begin{array}{l}\text { Sand, coarse } \\
\text { Sand and gravel }\end{array}$ & $\begin{array}{r}10 \\
6\end{array}$ & $\begin{array}{l}20 \\
26\end{array}$ \\
\hline
\end{tabular}

Well 25-6-20dal. City of Neligh

\begin{tabular}{|c|c|c|c|c|c|}
\hline $\begin{array}{l}\text { Clay, } \\
\text { Sand, coarse....... }\end{array}$ & $\begin{array}{r}5 \\
10 \\
4\end{array}$ & $\begin{array}{r}5 \\
15 \\
19\end{array}$ & Sand and gravel & $\begin{array}{l}3 \\
8\end{array}$ & $\begin{array}{l}22 \\
30\end{array}$ \\
\hline \multicolumn{6}{|c|}{ Well 25-6-20da2. } \\
\hline $\begin{array}{l}\text { Soil } \\
\text { Sand } \\
\text { Clay, silty }\end{array}$ & $\begin{array}{r}7 \\
10 \\
3\end{array}$ & $\begin{array}{r}7 \\
17 \\
20\end{array}$ & $\begin{array}{l}\text { Sand } \\
\text { Gravel } \\
\text { Sandstone }\end{array}$ & $\begin{array}{r}4 \\
2.5 \\
.5\end{array}$ & $\begin{array}{l}24 \\
26.5 \\
27\end{array}$ \\
\hline
\end{tabular}

Test hole 25-6-27bb1. Layton Baker

Soil.

Clay, sandy

Clay, yellow.

Clay, sandy.

Sand; some gravel

Clay, blue.

Sand, fine: some clay

Sand, fine, silty

\begin{tabular}{c|c|}
2.5 & 2.5 \\
9.5 & 12 \\
13 & 25 \\
3 & 28 \\
7 & 35 \\
4 & 39 \\
13 & 52 \\
9 & $6 \mathrm{I}$ \\
\hline
\end{tabular}

Sand, fine.

Clay, sandy

Sandstone, sandy white clay.

Clay, sandy, white

Sand, fine....

Clay, sandy, white...................

Sandstone, fine ................. 47

\begin{tabular}{r|r}
33 & 94 \\
8 & 102 \\
13 & 115 \\
10 & 125 \\
12 & 137 \\
14 & 151 \\
47 & 198
\end{tabular}


TABLE 5.-Logs of test holes and wells, Elkhorn River basin, Nebraska-Continued

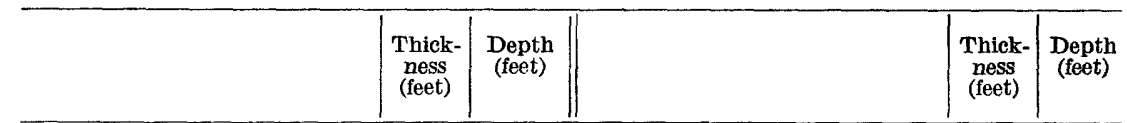

\section{ANTELOPE COUNTY-Continued}

Well 25-6-27bb2. Layton Baker

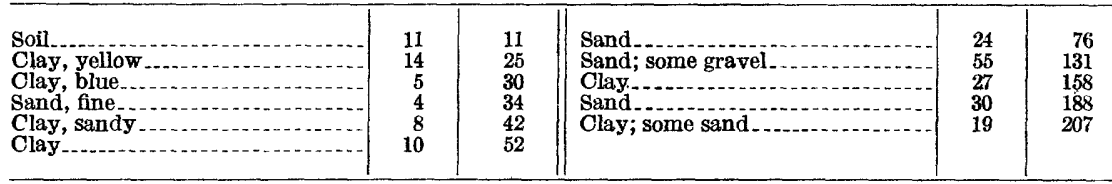

\section{Well 25-7-3dbl. Oscar Larson}

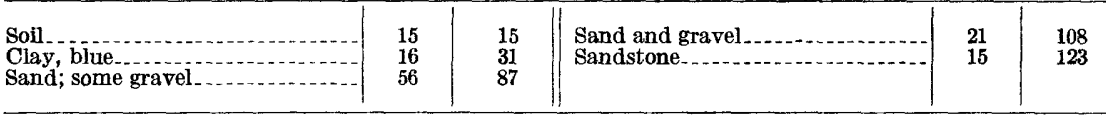

Test hole 25-7-3db2. Oscar Larson

\begin{tabular}{|c|c|c|c|c|c|}
\hline $\begin{array}{l}\text { Soil } \\
\text { Sand, blue and gravel } \\
\text { Clay }\end{array}$ & $\begin{array}{r}42 \\
6 \\
22 \\
4\end{array}$ & $\begin{array}{l}42 \\
48 \\
70 \\
74\end{array}$ & $\begin{array}{l}\text { Sand; some clay layers. } \\
\text { Clay } \\
\text { Sandstone }\end{array}$ & $\begin{array}{r}46 \\
24 \\
1\end{array}$ & $\begin{array}{l}120 \\
144 \\
145\end{array}$ \\
\hline
\end{tabular}

Test hole 25-7-12ac1. H. C. Greeley

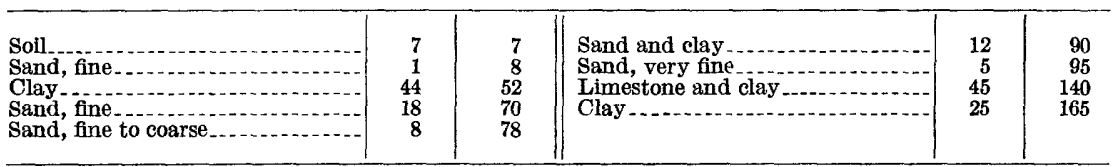

Well 25-7-12ac2. H. C. Greeley

\begin{tabular}{|c|c|c|c|c|c|}
\hline $\begin{array}{l}\text { Soil } \\
\text { Sand, fine } \\
\text { Sayd, fine to coarse } \\
\text { Sand }\end{array}$ & $\begin{array}{r}7 \\
2 \\
40 \\
41\end{array}$ & $\begin{array}{r}7 \\
9 \\
49 \\
90\end{array}$ & $\begin{array}{l}\text { Limestone, } \\
\text { Sand, very fine. }\end{array}$ & $\begin{array}{r}3 \\
23 \\
8\end{array}$ & $\begin{array}{r}93 \\
116 \\
124\end{array}$ \\
\hline
\end{tabular}

Well 25-7-12ad. H. C. Greeley

\begin{tabular}{|c|c|c|c|c|c|}
\hline Soil & 23 & 23 & Clay & 1 & 71 \\
\hline Clay, blue & 25 & 48 & Sand, fine; some clay and gravel.- & 15 & 86 \\
\hline Sand, medium. & 10 & 58 & Clay, sandy & 12 & 98 \\
\hline Sand, coarse & 2 & 60 & Clay & 20 & 118 \\
\hline Gravel $\ldots$ & 10 & 70 & Sand, fine; some clay & 24 & 142 \\
\hline
\end{tabular}

Well 25-7-12db. H. C. Greeley

\begin{tabular}{|c|c|c|c|c|c|}
\hline $\begin{array}{l}\text { Soil. } \\
\text { Sand } \\
\text { Slayd } \\
\text { Clay } \\
\text { Gravel. } \\
\text { Sand; some clay. }\end{array}$ & $\begin{array}{r}16 \\
21 \\
1 \\
4 \\
1 \\
12 \\
5\end{array}$ & $\begin{array}{l}16 \\
37 \\
38 \\
42 \\
43 \\
55 \\
60\end{array}$ & $\begin{array}{l}\text { Sand, fine, } \\
\text { Slay, fine } \\
\text { Sand, simestone, soft } \\
\text { Sand, fine; some clay } \\
\text { Limestone, hard }\end{array}$ & $\begin{array}{r}5 \\
11 \\
20 \\
23 \\
16 \\
10\end{array}$ & $\begin{array}{r}65 \\
76 \\
96 \\
119 \\
135 \\
145\end{array}$ \\
\hline \multicolumn{6}{|c|}{ Well 25-7-12dc. } \\
\hline $\begin{array}{l}\text { Soll. } \\
\text { Clay, blue } \\
\text { Sand, fine } \\
\text { Gravel, medium }\end{array}$ & $\begin{array}{r}15 \\
5 \\
15 \\
17\end{array}$ & $\begin{array}{l}15 \\
20 \\
35 \\
52\end{array}$ & $\begin{array}{l}\text { Limestone; some clay } \\
\text { Sand and clay } \\
\text { Sandstone }\end{array}$ & $\begin{array}{r}4 \\
12 \\
33\end{array}$ & $\begin{array}{r}56 \\
68 \\
101\end{array}$ \\
\hline
\end{tabular}


TABLE 5.-Logs of test holes and wells, Elkhorn River basin, Nebraska-Continued

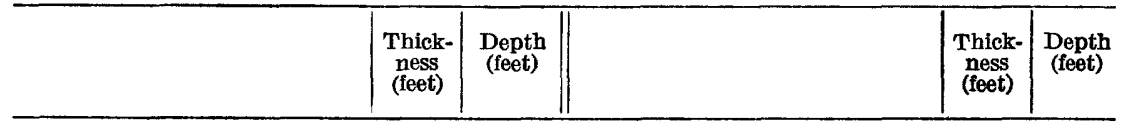

ANTELOPE COUNTY-Continued

Well 25-5-17aa. Emery Berg

\begin{tabular}{|c|c|c|c|c|c|}
\hline $\begin{array}{l}\text { Soil } \\
\text { Sand and gravel } \\
\text { Clay }\end{array}$ & $\begin{array}{r}57 \\
77 \\
2\end{array}$ & $\begin{array}{r}57 \\
134 \\
136\end{array}$ & $\begin{array}{l}\text { Sand and gravel } \\
\text { Sandstone. }\end{array}$ & $\begin{array}{l}27 \\
16\end{array}$ & $\begin{array}{l}163 \\
179\end{array}$ \\
\hline
\end{tabular}

HOLT COUNTY

Well 28-12-1da. City of $O^{\prime}$ Neill

\begin{tabular}{|c|c|c|c|c|c|}
\hline $\begin{array}{l}\text { Sand, fine to coarse } \\
\text { Sand, coarse; some gravel. } \\
\text { Sand, fine; some clay. } \\
\text { Sand, fine to coarse } \\
\text { Sand and gravel. } \\
\text { Sand, coarse; some gravel. }\end{array}$ & $\begin{array}{r}27 \\
5 \\
5 \\
20 \\
5 \\
20\end{array}$ & $\begin{array}{l}27 \\
32 \\
37 \\
57 \\
62 \\
82\end{array}$ & $\begin{array}{l}\text { Sand and gravel... } \\
\text { Sand, fine to coarse; some cemen- } \\
\text { tation. } \\
\text { Sandstone, fine, hard } \\
\text { Sandstone, soft; some hard zones. }\end{array}$ & $\begin{array}{r}20 \\
15 \\
5 \\
10\end{array}$ & $\begin{array}{l}102 \\
117 \\
122 \\
132\end{array}$ \\
\hline
\end{tabular}

Well 30-14-32abl. City of Atkinson

\begin{tabular}{|c|c|c|c|c|c|}
\hline $\begin{array}{l}\text { Soil, } \\
\text { Sand, coarse } \\
\text { Gravel } \\
\text { Slay, yellow } \\
\text { Sand, very fine. }\end{array}$ & $\begin{array}{r}3 \\
17 \\
5 \\
\mathbf{3} \\
\mathbf{2}\end{array}$ & $\begin{array}{r}3 \\
20 \\
25 \\
28 \\
30\end{array}$ & $\begin{array}{l}\text { Gravel. } \\
\text { Sand, coarse } \\
\text { Sand, lightly cemented. } \\
\text { Gravel, fine } \\
\text { Gravel, coarse }\end{array}$ & $\begin{array}{r}5 \\
6 \\
1 \\
11 \\
7\end{array}$ & $\begin{array}{l}35 \\
41 \\
42 \\
53 \\
60\end{array}$ \\
\hline
\end{tabular}

MADISON COUNTY

Test hole 23-3-30ab

\begin{tabular}{|c|c|c|c|c|c|}
\hline $\begin{array}{l}\text { Silt, clayey; some very fine to } \\
\text { coarse sand... } \\
\text { Silt, sandy, fine to coarse. } \\
\text { Sand, silty, fine to coarse. } \\
\text { Silt, sandy, very fine to medium } \\
\text { sand.-. } \\
\text { Sand, very fine to coarse, silty } \\
\text { Sand, fine to very coarse, silty } \\
\text { Sand, fine to coarse, silty } \\
\text { Sand, fine to medium, silty... } \\
\text { Sand, very fine to coarse; some } \\
\text { very coarse..... }\end{array}$ & $\begin{array}{l}42 \\
10 \\
11 \\
\\
21 \\
21 \\
10 \\
11 \\
20 \\
18\end{array}$ & $\begin{array}{r}42 \\
52 \\
63 \\
\\
84 \\
105 \\
115 \\
126 \\
146\end{array}$ & $\begin{array}{l}\text { Sand, very fine to medium, silty.- } \\
\text { Sand, very fine to very coarse..-- } \\
\text { Sand, very fine to medium, silty. } \\
\text { Silt... } \\
\text { Sand, silty; some gravel. } \\
\text { Sand, medium to coarse, silty } \\
\text { Sand, coarse to very coarse, silty.-- } \\
\text { Sand, medium to very coarse, } \\
\text { silty }\end{array}$ & $\begin{array}{r}9 \\
9 \\
9 \\
9 \\
9 \\
9 \\
9 \\
14 \\
\\
6\end{array}$ & $\begin{array}{l}173 \\
182 \\
191 \\
200 \\
209 \\
218 \\
232 \\
238\end{array}$ \\
\hline
\end{tabular}

Test hole 23-4-35aa

\begin{tabular}{|c|c|c|c|c|c|}
\hline $\begin{array}{l}\text { Soil. } \\
\text { Silt, some grayiclay } \\
\text { Sand, very fine to medium, some } \\
\text { coarse, silty } \\
\text { Sand, very fine to medium. } \\
\text { Sand, very fine to fine, some } \\
\text { medium, silty } \\
\text { Sand, very fine to fine, some } \\
\text { medium. }\end{array}$ & $\begin{array}{l}30 \\
20 \\
\\
34 \\
11 \\
20\end{array}$ & $\begin{array}{r}30 \\
50 \\
84 \\
95 \\
115 \\
147\end{array}$ & $\begin{array}{l}\text { Sand, very fine to fine; some silt } \\
\text { lenses. } \\
\text { Sand, very fine to fine, silty } \\
\text { Sand, very fine to medium, some } \\
\text { coarse, silty } \\
\text { Sand, very fine to coarse, silty; } \\
\text { some fine gravel. } \\
\text { Sand, very fine to coarse, silty } \\
\text { Sand and gravel; some sandy silt. }\end{array}$ & $\begin{array}{l}10 \\
21 \\
11 \\
\\
10 \\
11 \\
15\end{array}$ & $\begin{array}{r}157 \\
178 \\
189 \\
199 \\
210 \\
225\end{array}$ \\
\hline
\end{tabular}

\section{Well 24-4-25bc. City of Meadow Grove}

\begin{tabular}{|c|c|c|c|c|c|}
\hline Soil. Clay, blue. & $\begin{array}{l}7 \\
5\end{array}$ & $\begin{array}{r}7 \\
12\end{array}$ & $\begin{array}{l}\text { Sand, fine; some clay } \\
\text { Gravel }\end{array}$ & $\begin{array}{l}58 \\
15\end{array}$ & $\begin{array}{l}70 \\
85\end{array}$ \\
\hline
\end{tabular}


GROUND-WATER RHSOURCES, ELKHORN RIVER BASIN, NEBRASKA 745

TABLE 5.-Logs of test holes and wells, Elkhorn River basin, Nebraska-Continued

\begin{tabular}{|c|c|c|c|c|c|}
\hline & $\begin{array}{c}\text { Thick- } \\
\text { ness } \\
\text { (feet) }\end{array}$ & $\begin{array}{l}\text { Depth } \\
\text { (feet) }\end{array}$ & & $\begin{array}{c}\text { Thick- } \\
\text { ness } \\
\text { (feet) }\end{array}$ & $\begin{array}{l}\text { Depth } \\
\text { (feet) }\end{array}$ \\
\hline \multicolumn{6}{|c|}{$\begin{array}{l}\text { PFDRCE COUNTY } \\
\text { Test hole 25-4-27db }\end{array}$} \\
\hline $\begin{array}{l}\text { Sand, very fine to medium, gray, } \\
\text { silty } \\
\text { Sand, very fine to medium, some } \\
\text { coarse, silty } \\
\text { Sand, very fine to fine, some } \\
\text { medium, silty............. }\end{array}$ & $\begin{array}{r}25 \\
15 \\
5\end{array}$ & $\begin{array}{l}25 \\
40 \\
45\end{array}$ & $\begin{array}{l}\text { Sand, very fine to fine, silty } \\
\text { Sand, very fine to coarse... } \\
\text { Sand, fine to very coarse; some } \\
\text { fine gravel. }\end{array}$ & $\begin{array}{r}5 \\
12 \\
8\end{array}$ & $\begin{array}{l}50 \\
62 \\
70\end{array}$ \\
\hline \multicolumn{6}{|c|}{ Well 26-2-27aa. City of Pierce } \\
\hline Clay, sandy, yellow & $\begin{array}{l}16 \\
30\end{array}$ & $\begin{array}{l}16 \\
46\end{array}$ & $\begin{array}{l}\text { Gand, fine, white } \\
\text { Gravel... }\end{array}$ & $\frac{12}{22}$ & $\begin{array}{l}58 \\
80\end{array}$ \\
\hline \multicolumn{6}{|c|}{ Well 26-2-27ad3. City of Pierce } \\
\hline $\begin{array}{l}\text { Soil } \\
\text { Sand, yellow } \\
\text { Sand, dark-brown } \\
\text { Sand, fine, white } \\
\text { Clay, blue } \\
\text { Sand, coarse }\end{array}$ & $\begin{array}{l}2 \\
9 \\
9 \\
4 \\
1 \\
6\end{array}$ & $\begin{array}{r}2 \\
11 \\
20 \\
24 \\
25 \\
31\end{array}$ & $\begin{array}{l}\text { Sand, fine } \\
\text { Sand, coarse, gray } \\
\text { Sand, coarse, red } \\
\text { Sand, coarse, glacial drift, } \\
\text { Sand, very fine }\end{array}$ & $\begin{array}{r}8 \\
14 \\
10 \\
13 \\
\mathbf{3}\end{array}$ & $\begin{array}{l}39 \\
53 \\
63 \\
76 \\
79\end{array}$ \\
\hline
\end{tabular}

STANTON COUNTY

Well A23-2-20cd2. City of Stanton

\begin{tabular}{|c|c|c|c|c|c|}
\hline $\begin{array}{l}\text { Clay } \\
\text { Sand, fine } \\
\text { Clay, sandy }\end{array}$ & $\begin{array}{r}28 \\
7 \\
2\end{array}$ & $\begin{array}{l}28 \\
35 \\
37\end{array}$ & $\begin{array}{l}\text { Sand, coarse } \\
\text { Gravel, coarse }\end{array}$ & $\begin{array}{r}7 \\
16\end{array}$ & $\begin{array}{l}44 \\
60\end{array}$ \\
\hline
\end{tabular}

Well A23-3-19bc. W. A. Schultze

\begin{tabular}{|c|c|c|c|c|c|}
\hline $\begin{array}{l}\text { Olay, silty. } \\
\text { Silt, sandy } \\
\text { Sand, white } \\
\text { Sand. } \\
\text { Gravel, fine to coarse. }\end{array}$ & $\begin{array}{r}10 \\
8 \\
12 \\
11 \\
11\end{array}$ & $\begin{array}{l}10 \\
18 \\
30 \\
41 \\
52\end{array}$ & $\begin{array}{l}\text { Gravel, fine } \\
\text { Gravel, coarse } \\
\text { Gravel, very coarse } \\
\text { Clay, blue. }\end{array}$ & $\begin{array}{r}5 \\
10 \\
5 \\
3\end{array}$ & $\begin{array}{l}57 \\
67 \\
72 \\
75\end{array}$ \\
\hline
\end{tabular}

Well A24-3-35ca3. City of Pilger

\begin{tabular}{|c|c|c|c|c|c|}
\hline $\begin{array}{l}\text { Olay, } \\
\text { Sand, fine. }\end{array}$ & $\begin{array}{l}4 \\
7 \\
7\end{array}$ & $\begin{array}{r}4 \\
11 \\
18\end{array}$ & $\begin{array}{l}\text { Sand, fine } \\
\text { Sand and siltt } \\
\text { Sand and gravel. }\end{array}$ & $\begin{array}{l}10 \\
4 \\
20.5\end{array}$ & $\begin{array}{l}28 \\
32 \\
52.6\end{array}$ \\
\hline
\end{tabular}




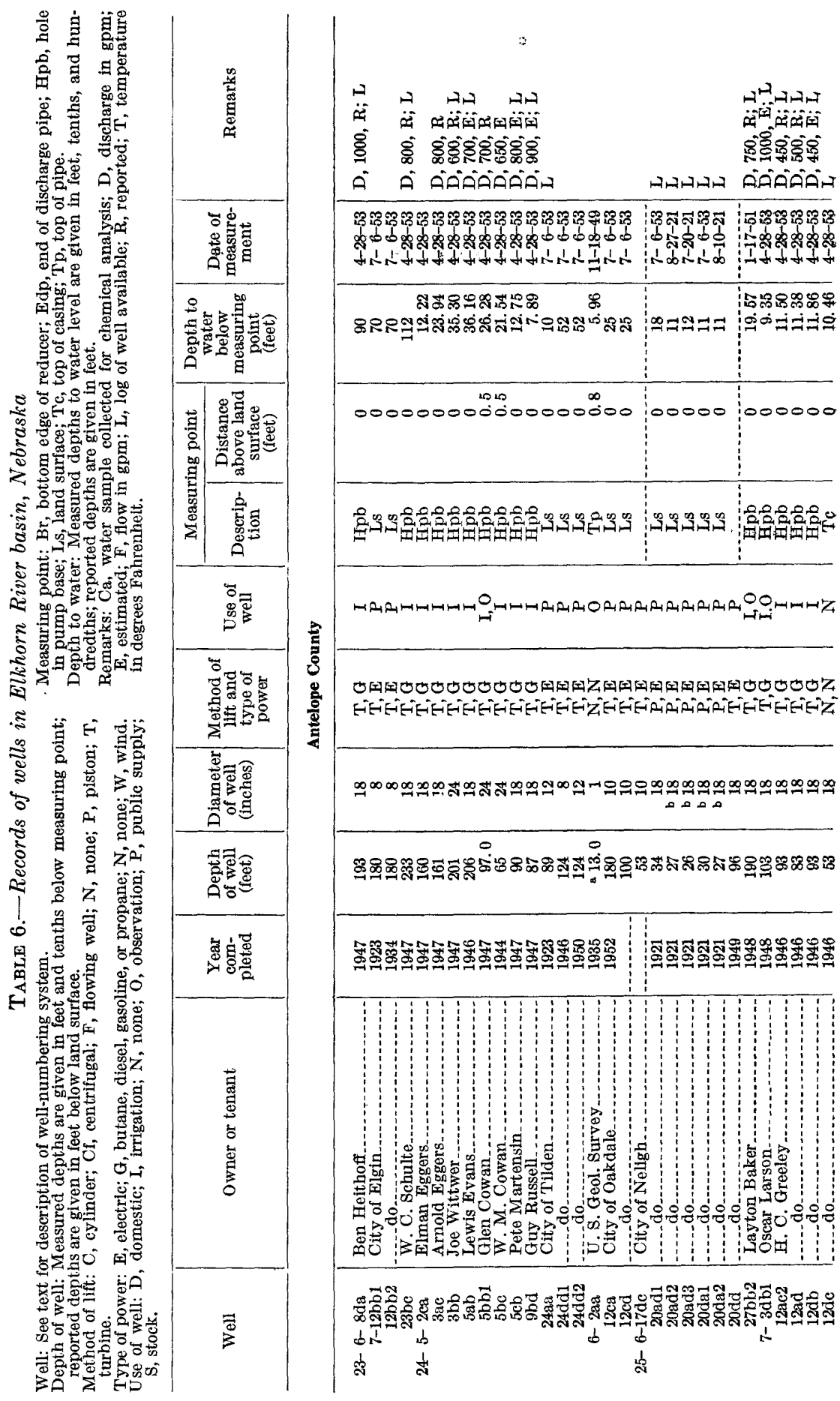




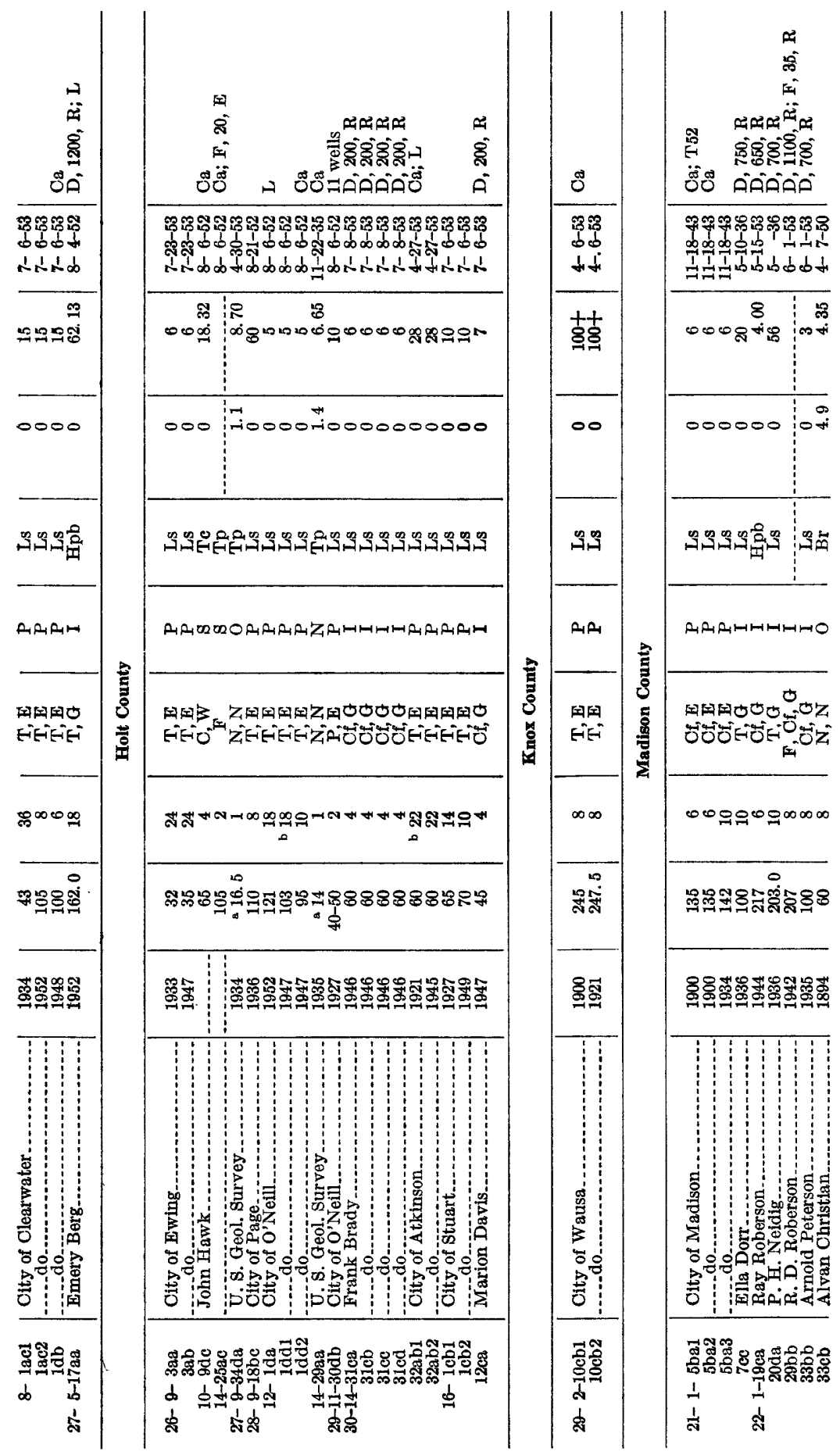



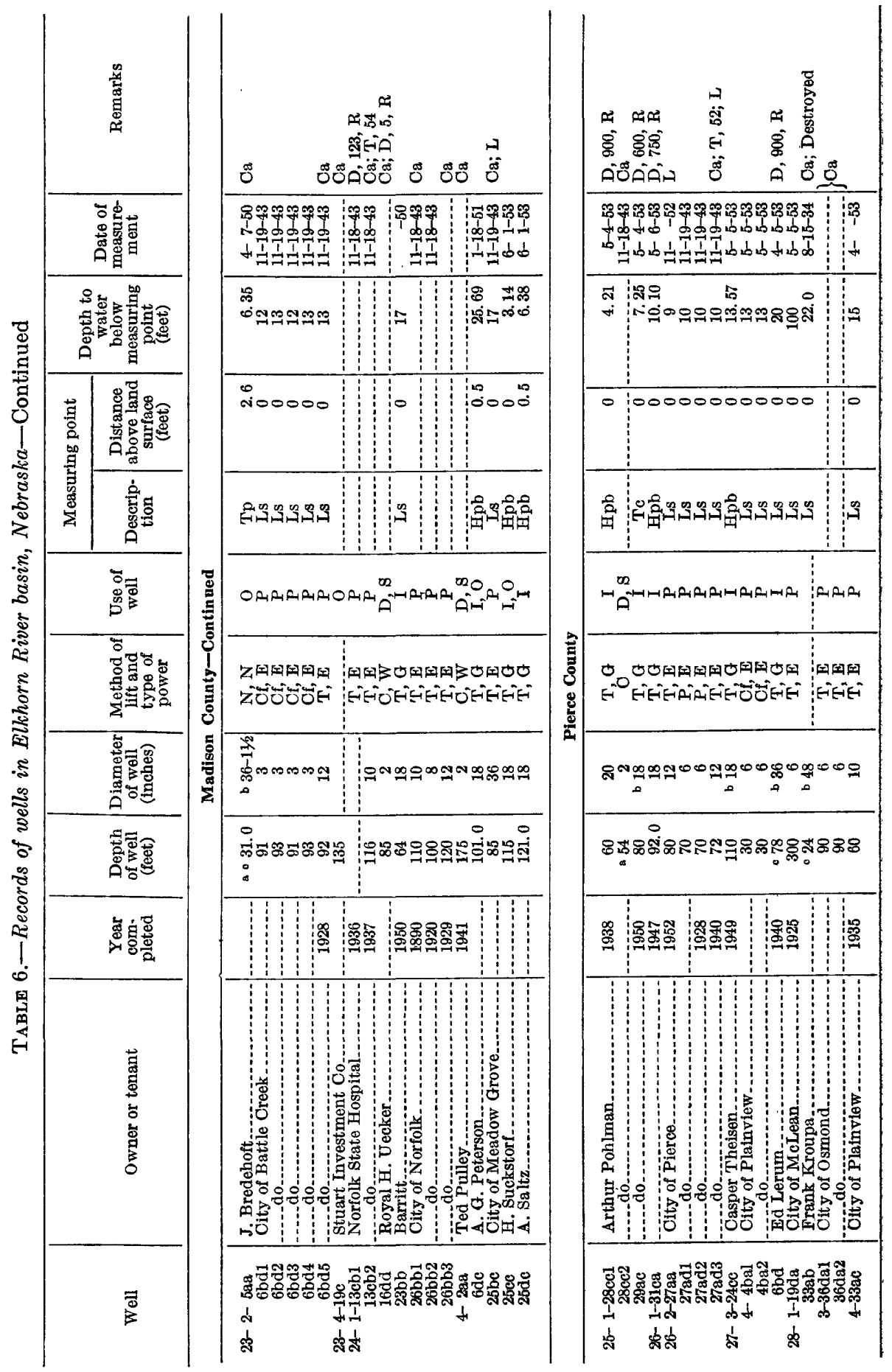


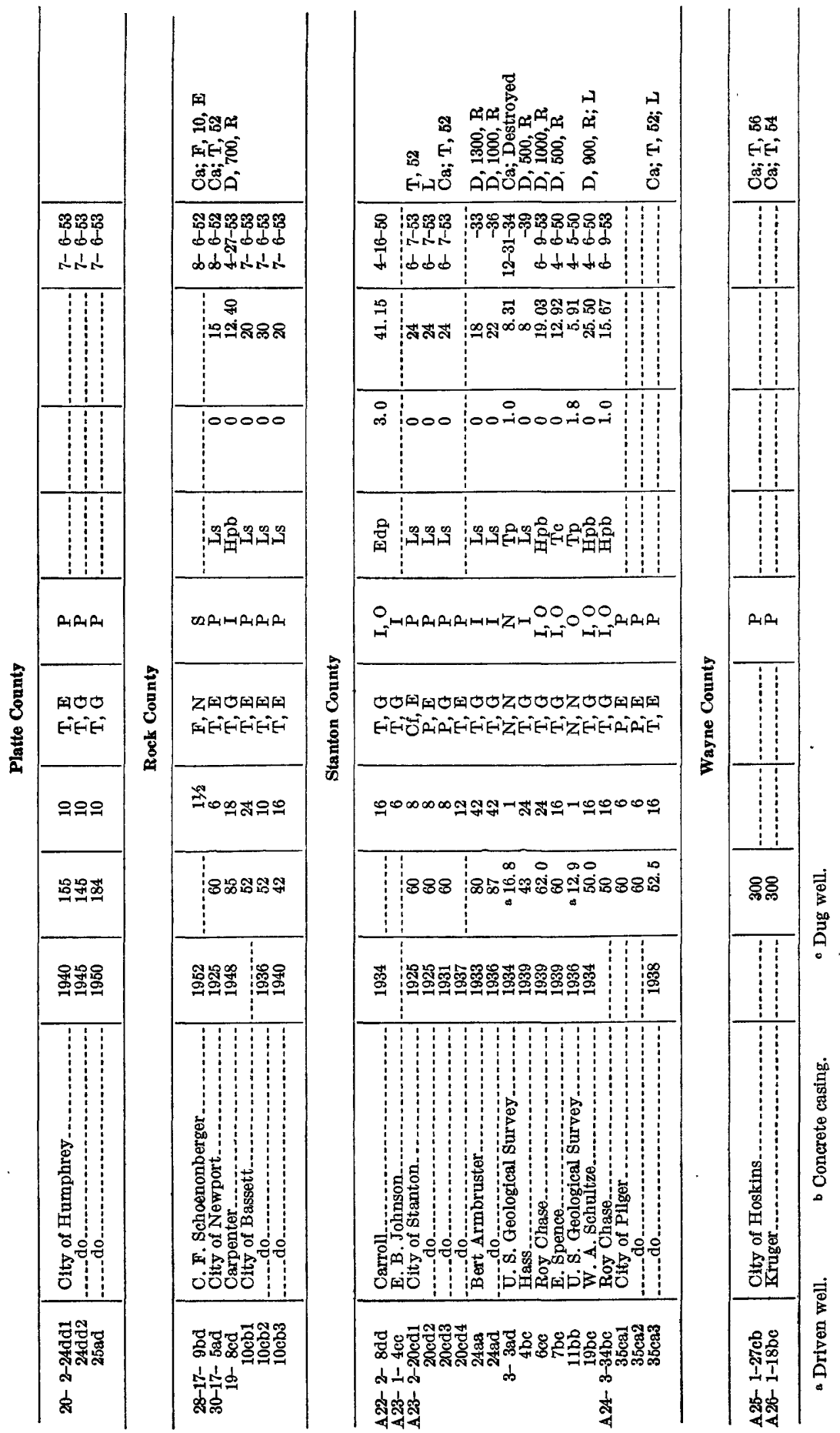




\section{SELECTED BIBLTOGRAPHY}

Condra, G. E., and Reed, E. C., 1936, Water-bearing formations of Nebraiska: Nebr. Geol. Survey Paper 10, 24 p.

Describes the water-bearing formations and occurrence of ground water; presents maps of bedrock, mantle rock, and ground-water regions; includes generalized geologic sections.

1943, The geologic section of Nebraska: Nebr. Geol. Survey Bull. 14, 82 p.

Describes age relations and general lithologic character of the rock formations of Nebraska.

Condra, G. E., Reed, E. C., and Gordon, E. D., 1947, Correlation of the Pleistocene deposits of Nebraska: Nebr. Geol. Survey Bull. 15, 73 p.

Correlates and describes the deposits of Pleistocene age and shows their areal distribution in Nebraska; discusses water-table fluctuations during the epoch.

Condra, G. E., Schramm, E. F., and Lugn, A. L., 1931, Deep wells of Nebraska: Nebr. Geol. Survey Bull. 4, 288 p.

Describes and discusses logs of deep wells in Nebraska.

Eaton, F. M., 1950, Significance of carbonates in irrigation water: Soil Sci., v. 69, no. 2 , p. 123-133.

Fenneman, N. M., 1931, Physiography of Western United States: New York, McGraw-Hill Book Co., Inc., p. 11-12.

Describes physiographic areas of the Western United States, including the High Plains, the loess plains, and the Sand Hills of Nebraska.

Keech, C. F., and Case, R. L., 1954, Water levels prior to January 1, 1954, in obser.vation wells in Nebraska: U. S. Geol. Survey mimeo. rept., pts. 1 and $2 .$. p. $1-543$.

Presents all water-level measurements made in observation wells in Nebraska before January 1, 1954, that are not in other published form.

1955, Water levels in observation wells in Nebraska during 1954: U. S. Geol. Survey mimeo. rept.

Presents all water-level measurements made in observation wells in Nebraska during 1954 that are not in other published form.

Keech, C. F., and Schreurs, R. L., 1953, Logs of test holes, Madison and Pierce Counties, Nebr., 1931 to 1953, inclusive: U. S. Geol. Survey and Nebr. Conserv. and Survey Div. Pamph., 41 p.

-1953, Logs of test holes, Stanton County, Nebr., 1931 to 1952, inclusive: U. S. Geol. Survey and Nebr. Conserv. and Survey Div. Pamph., 25 p.

Lugn, A. L., 1935, The Pleistocene geology of Nebraska: Nebr. Geol. Survey Bull. 10, 223 p.

Discusses ground water in relation to Pleistocene deposits; includes a geologic section.

Maxcy, K. F., 1950, Report on the relation of nitrate concentrations in well waters to the occurrence of methemoglobinemia: Natl. Research Council Bull., Sanitary Engineer, p. 265, app. D. 
Reed, E. C., 1944, Ground-water survey of area north of O'Neill, Holt County, Nebr.: Nebr. Conserv. and Survey Div., Nebr. Water Survey Paper 2, 26 p.

Gives results of a study of possibilities of irrigating with ground water a 70square-mile area northwest from $O^{\prime} \mathrm{Neill}$; gives records of 13 wells; describes the geology, topography, drainage, soils, and ground water.

U. S. Geol. Survey, 1935-54, Water levels and artesian pressure in observation wells in the United States: U. S. Geol. Survey Water-Supply Papers 777, $817,840,845,886,908,938,946,988,1018,1025,1073,1098,1128,1158$, $1167,1193,1223,1267$, and 1323.

Annual reports giving water-level measurements made in key observation wells.

United States Public Health Service, 1946, Drinking-water standards: Pub. Health Service Repts., v. 61, no. 11, p. 371-384.

United States Salinity Laboratory Staff, 1954, Diagnosis and improvement of saline and alkali soils: U. S. Dept. Agriculture, Agriculture Handb. 60. 


\section{INDEX}

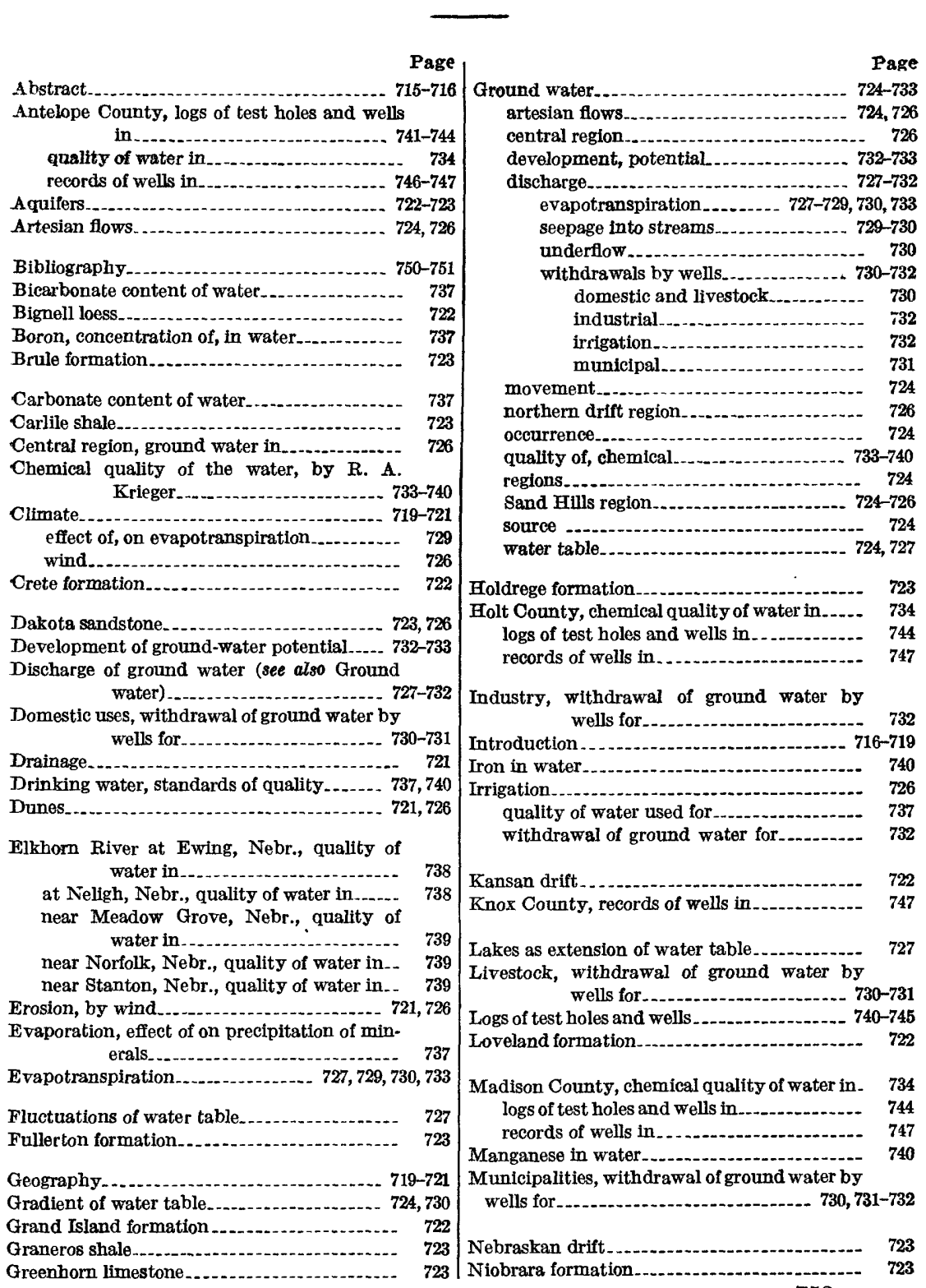


North Branch at Pierce, Nebr., quality of water in

Northern drift region, ground water in.

Ogallala formation

Peorian loess.

Pierce County, chemical quality of water in.. logs of test holes and wells in records of wells in

Pierre shale.

Platte County, records of wells in.

Precipitation $719-721,724,726,729$

Quality of water, chemical, in relation to use - 736-740

Rainfall. (See Precipitation.)

Rock County, chemical quality of water in .... records of wells in

Runoff.

Sand, dune 721,726

Sand Hills region $721,724-726,733$ ground water in 724-726

Sappa formation - 722

Seepage of ground water into streams.

Tor
seepage into streams............... 729

South Fork near Ewing, Nebr., quality of water in

Stanton County, chemical quality of water in. $\quad 735$

logs of test holes and wells in ............... $\quad 745$

records of wells in . . . . . . . . . . .

Stratigraphy ............ 721-724

Test holes. (See Wells.)

Todd Valley formation...................... $\quad 722$

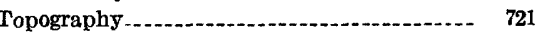

Underflow, discharge of ground water by ..... $\quad 730$

Use of water, chemical quality of water in

relation to.................... 736-740

735 Water table ................... 724, 726, 727, 730, 732

Wayne County, chemical quality of water in.- 735

records of wells in....................... 749

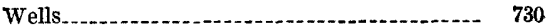

system of numbering . . 718-719

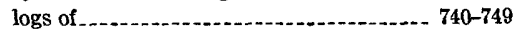

withdrawals by ......................... 730-732

Wind, erosion by

729-730 withdrawals of ground water by wells...... 730-732 


\section{Contributions to the}

Hydrology of the

\section{United States, 1955}

GEOLOGICAL SURVEY WATER-SUPPLY PAPER 1360

This volume was printed as

separate chapters $A-I$

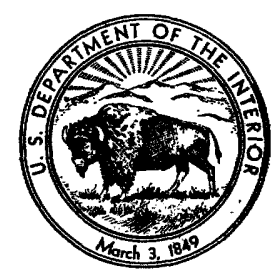




\section{UNITED STATES DEPARTMENT OF THE INTERIOR}

FRED A. SEATON, Secretary

\section{GEOLOGICAL SURVEY}

Thomas B. Nolan, Director 


\section{CONTENTS}

[The letters in parentheses preceding the titles designate separately published chapters]

(A) Reservoirs in the United States, by Nathan O. Thomas and G. Earl

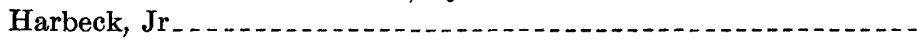

(B) Ground water in northeastern Louisville, Ky., by M. I. Rorabaugh.-

(C) Geology and occurrence of ground water in the Townsend Valley, Mont., by H. W. Lorenz and R. G. McMurtrey

(D) Water resources of Bill Williams River valley near Alamo, Ariz., by H. N. Wolcott, H. E. Skibitzke, and L. C. Halpenny

(E) Geology and ground-water resources of the Kaycee irrigation project, Johnson County, Wyo., by F. A. Kohout

(F) Salt water and its relation to fresh ground water in Harris County, Tex., by Allen G. Winslow, William W. Doyel, and Leonard A. Wood

(G) Ground-water conditions in the Mendota-Huron area, Fresno and Kings Counties, Calif., by G. H. Davis and J. F. Poland.......-

(H) Geology and ground-water hydrology of the valleys of the Republican and Frenchman Rivers, Nebr., by Edward Bradley and Carlton R. Johnson

(I) Reconnaissance of the ground-water resources of the Elkhorn River basin above Pilger, Nebr., by Thomas G. Newport. . . . . . . . 
. 